How to Cite: Bhole, R.P., Shinde, Yogita, Bonde, C.G., \& Wavhale, R.D. Vitamin Drug conjugate: a systematic review of pharmacological potential. (2021) Phosphorylation of glycoluryl derivatives with phosphorus pentachloride. Bulletin of the University of Karaganda - Chemistry, 101(1), 27-52. https://doi.org/10.31489/2021Ch1/27-52

\author{
R.P. Bhole ${ }^{1 *}$, Yogita Shinde ${ }^{1}$, C.G. Bonde ${ }^{2}$, R.D. Wavhale ${ }^{1}$ \\ ${ }^{I}$ Dr. D.Y. Patil Institute of Pharmaceutical Sciences and Research, Pimpri, Pune, Maharashtra, India; \\ ${ }^{2}$ SVKM's, NMIMS School of Pharmacy, Shirpur, Dist: Dhule, India \\ (*Corresponding author's e-mail: ritesh.bhole@dypvp.edu.in)
}

\title{
Vitamin Drug conjugate: a systematic review of pharmacological potential
}

\begin{abstract}
Cancer is a chronic disease which can cause death. In traditional chemotherapy cytotoxic drugs are used to kill proliferating cancer cells. The cytotoxic agent exhibits less specificity, less biological activity, causes systemic toxicity and undesirable side effects. Each year, about 1.8 million of the population are infected and die due to tuberculosis infection. An increase of drug resistance during the tuberculosis treatment is a significant concern. So, it is necessary to develop a new approach or therapies to resolve drug resistance, drug selectivity in tuberculosis infection and the reduction of the side effects of cytotoxic agents and anti-tubercular drugs. This review describes the newly emerging concept of «vitamin drug conjugate». Vitamin-drug conjugate is a specifically carried drug toward the target site, is one of the promising ways to treat chronic diseases like cancer and tuberculosis and enhance the therapeutic outcome. The purpose of this review is to explore vitamin as a targeting moiety for new anticancer and anti-tubercular drug to overcome challenges, such as nonselectivity, systemic toxicity and multidrug resistance. This approach is beneficial in the treatment of lifethreatening disease like cancer, tuberculosis and also in many viral infections.
\end{abstract}

Keywords: Cancer, Tuberculosis, Vitamin-Drug conjugate, Vitamin B12 conjugate, Folic acid conjugate, Biotin conjugate, Vitamin-E conjugate, Lipid drug conjugate.

\section{Content}

\author{
List of abbreviations \\ Review Plan \\ Introduction \\ 1 Vitamin-Drug conjugate \\ 2. Folic acid-drug conjugate \\ 3. Biotin Drug conjugate \\ 4. Vit-E-drug conjugate \\ 5.Vitamin-C Conjugate \\ 6. Lipid-Drug conjugate \\ 7. Polymer drug conjugate \\ Conclusions
}

\section{List of abbreviations}

WHO: World Health Organization

FRA: Folate Receptor Alpha

$\mathrm{B}_{12}$-Co-III-CN-M: Heterodinuclear derivative

MCF7: Human Breast cells

A2780: Human Ovary Cancer Cells

B12-Co-III-CN-Pt-II: Vitamin $\mathrm{B}_{12}$-Platinum conjugate

$\mathrm{N}_{4} \mathrm{PY}$ : Pentadentate Nitrogen ligand

$\mathrm{N}_{4} \mathrm{PY}-\mathrm{S}-\mathrm{S}-\mathrm{FA}$ : Redox sensitive cleavable linker

FRP: Folate Receptor Positive

AG: Arabinogalactan

FR-AG-GFCG-MTX: Folate receptor Arabinogalactan endosomal cleavable peptide of methotrexate MTX: Methotrexate

GFLG: Endosomal cleavable peptide

PLGA-PEG-FOL: Polylactideco-glycolide-polyethylene glycol-folate

$\mathrm{SKOV}_{3}$ : Folate receptor positive malignant cells

PEG: Polyethylene glycol 
PA-PEG-DSPE: Lipopolymer mPEG-DTP-DSPE: Lipopolymer

FA: Folic acid

PLGA: Polylactic-Co-glycolic acid

FU: 5-Fluorouracil

GG-NP: Guar gum loaded nanoparticles

MTX-FR-GGNP: Guar gum loaded methotrexate folic acid conjugated NP's

$\mathrm{G}_{5}$-MTX: Pentadentate dendrimer-MTX adduct

5BT-1214: New generation taxoid

TPG5: $\alpha$-Tocophenyl polyethylene glycol succinate

$\gamma-T_{3}$-Tocotrienol

$\mathrm{CoQ}_{10}$ : Ubiquinol

$\mathrm{CoQ}_{10} \mathrm{H}_{2}-\mathrm{PEG} 5000-\mathrm{V}$ it E: Ubiquinol-Polyethylene glycol-Vit- E Conjugate

SiRNA: Small interfering RNA

RNAi: RNA interference

TPGS: $\alpha$-Tocopheryl polyethylene glycol succinate

Aa-Su-Saq: Ascorbyl succinic-Saquinavir conjugate

CYP3A4: Cytochrome $\mathrm{P}_{450}$ metabolizing enzyme

MTX-PGA: Methotrexate-poly(glycerol adipate)

ATRA-g-PBEA: Docetaxel loaded trans-retinoic acid with poly- $\beta$-amino ester

HPMA: N-(2-Hydroxypropyl) methyl acrylamide

MA-Gly-Gly-NHN-Dex: Dexamethasone containing monomer

\section{Review Plan}

Inclusion and Exclusion Criteria: The present review is focused on vitamin drug conjugate, its synthetic methodology and its pharmacological screening.

The review data are based on the publication of the last 15 years and in English. Only articles in the relevant area were searched and analyzed from the sources like Scopus, Web of Science along with other online scientific search engines. The keywords used for the search were, 'Vitamin Drug Conjugate', 'anticancer activity, 'anti-tubercular activity', 'pharmacological screening', etc. The resultant data are described in this article. No statistical methods were used in this review.

\section{Introduction}

Cancer is an abnormal growth of the cells which tends to proliferate in an uncontrolled way and in some cases to metastasize [1]. There are many methods treating cancer, the most commonly applied one is chemotherapy, but the problem associated with that is non-selectivity in treatment. Severe, often life-threatening, side effects arise in cytotoxic chemotherapy because of the toxicity to susceptible normal cells as the treatment is not selective for tumor cells [2]. In the case of traditional chemotherapy, the most challenging step is to deliver a cytotoxic agent which kills proliferating cancer cells. [3]. The limitation of the used cytotoxic agents, such as doxorubicin, cisplatin, paclitaxel etc., is that these drugs cannot differentiate between tumor cells and normal healthy cells. In other words, non-specificity leads to systemic toxicity causing undesirable adverse effects like hair fall, kidney damage, lung and bone marrow $[4,5]$. Thereby it is challenging to deliver the anticancer drug to the tumor site. Thus, by this reason there is a need in urgent requirement to develop a targeted drug delivery system for the selective action of drugs toward the growing cancerous cells with minimum side effects. [5]. It is expected that marked medicines specifically taken up by target cells, can significantly improve the effectiveness of cancer therapy. In recent years, drugs containing different targeting ligands like polysaccharides, folate and peptides are tested to increase antitumor activity [6-10].

In order to eliminate such toxicities the methods have been developed under which the therapeutic agent is targeted by conjugation to a tumor-cell-specific small-molecule linker, thereby minimizing exposure to healthy cells and related side toxicity [11]. Delivering of the therapeutic agent with no affinity for normal cells but a strong affinity for abnormal cells with a targeting ligand is the best approach to improve safety and effectiveness of the drug. There are many advantages of targeted medications over their non-targeted equivalents. Besides, the targeted drugs can specifically distribute their medicinal payloads into the cancer cell, thus preventing non-specific absorption and related normal cell toxicity [12, 13]. In order to achieve effective tumor-targeting drug delivery, it should consists of tumor recognizing moiety and chemotherapeutic 
agent which directly connected through a linker. As a result conjugate acting 'prodrug' is formed which upon incorporated in cancer cell readily undergoes to splitting and regenerate the activity of cytotoxic agent [14].

All living cells need vitamins for survival and whereas the main physiological characteristic of cancer cell is an increased appetite for crucial vitamins because of their fast growth $[15,16]$. Thus, the receptor involved for the absorption of vitamins will be overexpressed on the surface of cancer cells. Crucial vitamins like Folic acid, biotin, Vitamin B12, and riboflavin are required for tumors rapid growth. One of the approaches is to combine the drugs with vitamins that detect tumor-associated antigens, which raise the sensitivity of cancerous cells to ligand-targeted therapeutics and decrease the exposure of healthy cells to drugs [2]. Recently, it is observed that the folate receptors are more overexpressed in the cancer cells in comparision to normal healthy cells. So, it is accepted that folate receptors may act as excellent biomarkers [16-20]. Folate receptor alpha (FRA) is overexpressed on the surface of multiple types of tumors, including cancer of the pancreas, liver, breast and ovary. Folate can bound to anticancer drugs. The best approach is targeting the FRA-positive tumor cells with several therapeutic probes using folic acid conjugates. Folate conjugates can achieve cancer-specific drug delivery with minimal toxicity [21-23]. Biotin acts as a growth promoter especially in the tumor, as compared to normal cells. Recently it has been reported that biotin receptors are also more overexpressed in the cancer cells like breast, lung, renal, ovarian in contrast to folate as well as vit. B12 receptors $[15,16]$. Combination of the anticancer drug with any particular vitamin gives vitamin-anticancer drug conjugate. Conjugation of anticancer agents with vitamin, has proven a novel prodrug approach, improving specificity with minimum side effects. The conjugation scaffold can improve potency as well as bioavailability of cytotoxic agents. The vitamin drug conjugate provides a high dose of a cytotoxic drug to the targeted cancer cell, so the essential vitamins like biotin, vitamin B12, folic acid, riboflavin may act as targeting moiety towards cancer cells. Most commonly, vitamin B12 and folic acid suggested as a targeting agent to tumor cell. Vitamin drug conjugate like folic acid -drug conjugate, Vit.B12-drug conjugate, biotin -drug conjugate and Vit.E-drug conjugate, as well as vitamin C-drug conjugate are listed in this review.

Other than cancer, tuberculosis is also one of the chronic illness, so there is an urgent need to find an effective treatment against chronic tuberculosis infection. Mycobacterium tuberculosis is the pathogen agent causing the infectious disease tuberculosis. Tuberculosis is one of the terrible human diseases which infects about 9 million of the population, including 1.5 million deaths in 2013 as per the WHO survey [24]. Drugs used for the treatment of TB are categorized into two groups; first-line drug and second-line drugs. The most commonly used first-line drugs for the treatment of tuberculosis are Isoniazid, Rifampicin, Ethambutol and pyrazinamide [25]. These drugs develop multidrug resistance because of the lengthy period of treatment, mostly 12-18 months or more [26]. Thereby there is a need of searching for a new anti-tubercular agent or other supportive therapy [27]. Vitamins also play a crucial role to prevent the spread of this chronic illness. Any bacteria like mycobacterium tuberculosis needs essential vitamins like biotin, thiamin to fulfil their requirement and to initiate their infection. Vitamin $\mathrm{C}$, for instance, has antimycobacterial property. Vitamins act as a promising agent to change life cycle as well as the biology of mycobacterium tuberculosis and helps to stop the spread of infection [27]. Lipid drug conjugate improving the bioavailability of the anti-tubercular drug by incorporation of short lipid chain is discussed in this review. Limitations associated with the antitubercular drugs like Isoniazid, Rifampicin, Ethambutol and pyrazinamide is liphophilicity issue resulting poor blood-brain barrier penetration. Lipid-antitubercular drug conjugate is also a new approach having potential to enhance efficacy, bioavailability, with reduction in drug resistance.

Vitamin drug conjugate is the novel term that provides selective delivery of cytotoxic agent towards cancer cells with desirable therapeutic effect. This review focuses on the requirements that must be met to achieve the necessary therapeutic efficacy with minimal side effects during the design of vitamin drug conjugate. This review also emphasises on various vitamin drug conjugate reported to date with its synthetic methodology and pharmacological evaluation. Vitamin drug conjugates like folic acid drug conjugate, vitamin B12, biotin, vitamin E, vitamin C-conjugates are listed in this review. All these conjugates were studied to find out the best fit conjugate in terms of its clinical applicability.

\section{Vitamin-Drug conjugate}

Vitamin-Drug conjugate is considered as a targeted drug delivery system for tumors. It generally consists of the drug connected directly or through a linker to the targeted moiety to form an active pharmacological object, i.e the 'vitamin-Drug conjugate' (Fig. 1). The benefits of vitamin drug conjugate are nontoxic and 
it must be stable in circulation and do not harm to normal cells. Upon entry of this conjugate into the cancer cells, it should effectively release the anticancer drug without losing biological activity [5, 28].

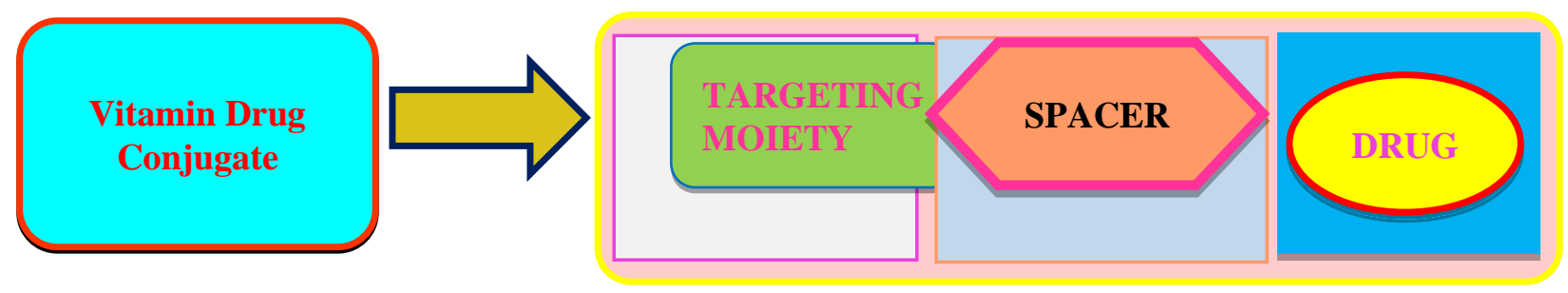

Figure 1 Vitamin-drug conjugate

\subsection{Vitamin B12- drug conjugate [30].}

\subsubsection{Vit-B $B_{12}$-metal conjugate}

The cancer cells need vitamin B12 and more cellular uptake, so it can be concluded that on conjugation with vit. B12 increases tumor selectivity and enhance therapeutic outcomes. This type of conjugate consists of an anticancer drug with tumor imaging metal-containing compound [31]. A variety of vitamin B12 metal analogues are identified to date, but some provide a promising proof of concept promoting the use of cobalamins in targeted chemotherapy and diagnosis as metal-based medicine and imaging drug carriers $[31,32]$. There are number of studies on platinum and other metal-based anticancer agents, but on other hand the clinically established anticancer drug cisplatin has some disadvantages, like low bioavailability, watersolubility, lack of tumor selectivity and undesirable side effects proved. In spite of its harmfulness the platinum complex was clinically approved and accepted because of its pharmacological activity with less side effects [31, 33-34].

\section{Platinum}

Cisplatin is also platinum-based drug with anticancer activity. However there are some disadvantages of this drug, such as nephrotoxicity, neurotoxicity, phototoxicity, nausea etc. Alberto et al. developed a method to overcome the problem associated with anticancer drug cisplatin and its side effects. Conjugation of cisplatin with cobalamine (vit B12) increases tumor selectivity and enhance the clinical output $[31,35,36]$. Metal containing scaffolds is attached to the nitrogen atom to the cyano group on vit B12, producing a derivative (B12-Co-III-CN-M) where vitamin is functioning as a ligand. A further step is vitamin B12 converted to its cofactor (either methylcobalamine or adenosylcobalamin) required for reduction of Co (III) to Co (II) by removing bioactive molecule Vit.B12 Co III. CN is mixed with metal. The formed cyano metal fragment (CN-M) release directly inside the cell. This cyanocobalamine metal conjugate (Figure 2) considered as prodrug, which shows the clinical endpoint $[31,36]$.

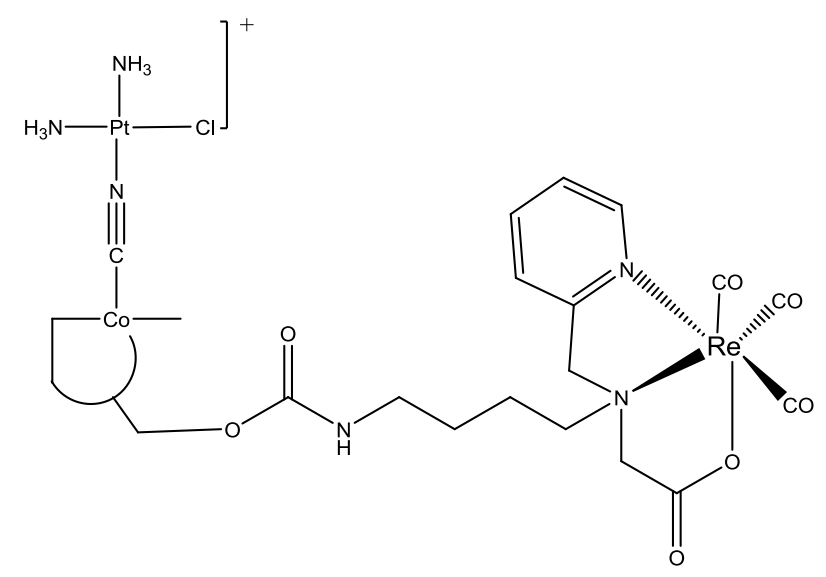

Figure 2. Vitamin B12-Platinum Conjugate 
In vitro cytotoxicity experimental investigation on adenocarcinoma of human breast cells (MCF7) and adenocarcinoma of cells of human ovary(A2780) demonstrated that differentiated Pt (II-Cyano complexes exhibited antitumor action equivalent to that seen in cisplatin, suggesting that (B12-CoIII-CN-PtII) analogue should be considered as an active drug because they have an affinity to generate Pt-II containing antitumor drug quickly in the body effectively. Unfortunately, this theory was not compatible with the data that the original analogues were less carcinogenic than cisplatin [31,37].

\subsubsection{Colchicine-Cobalamins conjugate}

Colchicine functions as a spindle toxin with a mode of action close to that of taxanes, and it also acts as a cytotoxic agent. Colchicine inhibits the polymerization of tubulin and prevents cancer cell proliferation at metaphase in mitosis. But colchicine has not proven effective for cancer therapy to date because of its overbearing toxic effects that cause undesirable side effects at endovenously medication [38-40]. Using the cobalamin leads to selective delivery of colchicine to tumor cells, the side effects associated with colchicine can decrease drastically [38].

Joshua et al., developed colchicine-cobalamin conjugate (Fig. 3). By substitution at the C7 position of colchicine by $\mathrm{p}$-alkoxy-acetophenone and bonded with cobalamin via hydrazone, which has acid sensitive nature. Malignant cells are more likely prone to cellular absorption of this scaffold. Upon interaction of this scaffold with cancer cells occurs hydrolysis of the acid liable hydrazone linker inside the lysosome. Colchicine behaves as a powerful antineoplastic agent, helps to balance the microtubule as well as shows cellular apoptosis. This scaffold is highly stable at $\mathrm{pH} 7$ and in the cellular medium, is more susceptible to hydrolysis at $\mathrm{pH}$ 4.5, having a half-life of $138 \mathrm{~min}$. This scaffold display LC50 values in nanomolar across the variety of cancer cell such as brain, breast and melanoma in cellular medium. The increase of the drug's bioavailability by overcoming the undesirable side effects associated with tubulin can be achived by adding colchicine to cobalamin. The in vitro cytotoxicity of this bioconjugate is equivalent to that of existing chemotherapy medications such as paclitaxel and docetaxel. However, bioconjugate is highly soluble in water and considerably inexpensive than paclitaxel or docetaxel [38, 41-43].

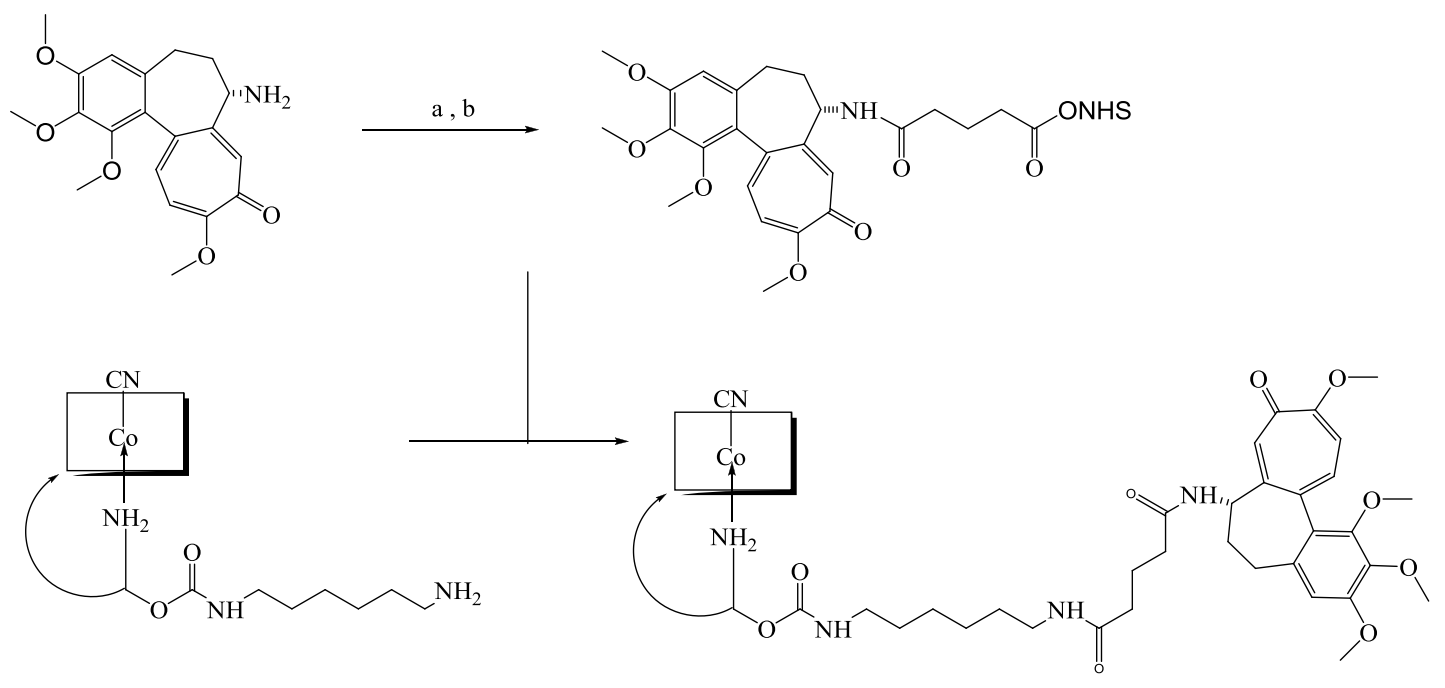

(a) Glutaric anhydride in DMSO : (b) EDCI, NHS in DMSO ( 34\% yield, 3 steps )

Figure 3. Synthesis of colchicine cobalamine conjugate

\section{Folic acid-drug conjugate}

Folic acid is one of the essential vitamins, and folate receptors act as a target for the cancer treatment [44]. The folate receptors are recently emerged as a promising theragnostic target due to their great functional flexibility in multiple solid tumors [45]. The major problem is the delivery of anticancer drug due to nonselectivity, which result in toxicity because having an inability to distinguish between cancer and normal healthy cells. This problem can be resolved by conjugating anticancer drug with folic acid. Folic acid acts as a targeting ligand to deliver many therapeutic agents towards growing tumors tissues. Folic is used as a tar- 
get because it easy conjugate with therapeutic, as well as diagnostic agent and also shows a high affinity towards the folate receptor. Most important that folate receptor is limitly distributed in the normal cell, but overexpressed in cancer cells [46]. This foremost approach involves linking FA to the anticancer drug forming small molecule drug compound to get effectual clinical output. Folate conjugate attached to folate receptor by means of endocytosis process, which is overexpressed in cancer cells and attached drug shows its therapeutic output after cellular administration. [44].

\subsection{Folic acid-Bleomycin conjugate}

Most challenging step in cancer therapy is to deliver anticancer drug due to their non-selectivity and systemic toxicity [47]. Bleomycin acts as an anticancer antibiotic. The problem associated with bleomycin is short half-life, less clinical output and more undesirable side effect. Due to this problem, there is limited use of bleomycin as a therapeutic agent in cancer therapy [48].

Geersing et al., developed a method which shows that bleomycin imitates conjugate of folic acid (Fig. 4) where folic acid conjugate with pentadentate nitrogen ligand(N4Py) through a cleavable di-sulphide linker. This conjugate exibits promising efficacy and selective delivery of the anticancer drug in cancer cells which are overexpressed toward folate receptor. This conjugate also increases potency as well as selectivity of cytotoxic anticancer agent. A significant effect was seen by the MTS assay conducted in KB cells on N4Py-S-S-FA metabolic function after $48 \mathrm{~h}$, which is enhanced after 72 hours. Pentadentate iron ligand conjugated with folic acid can induce selective apoptosis of FR (+) cancerous cells in contrast with a minimum effect observed for FR (-) cells. Enhanced efficacy is observed after a duration of $72 \mathrm{hrs}$ due to the existence of a disulphide bond-containing cleavable linker moiety. These observations demonstrate the strength of therapeutics targeted by ligands, with strong potency and improved selectivity relative to compounds without targeted moiety [47, 49-51].

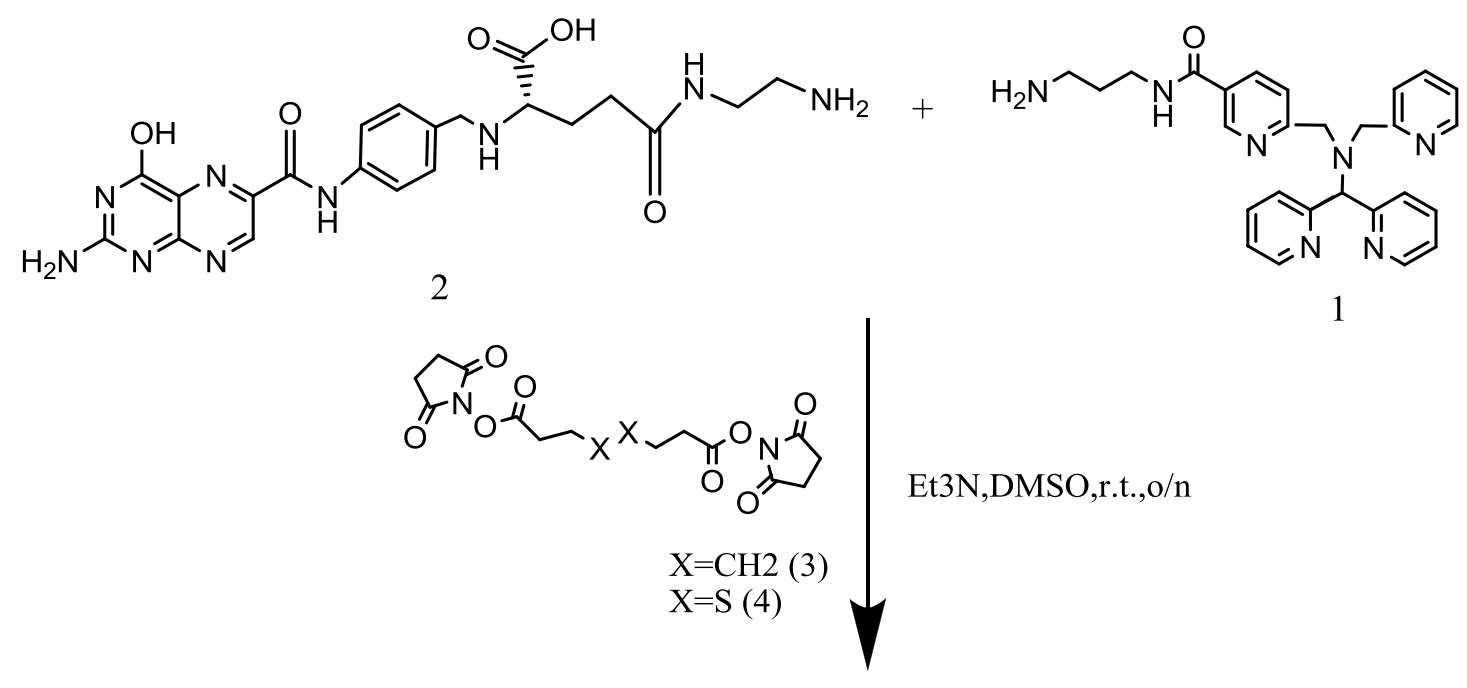<smiles>[X]CCC(=O)NCCNC(=O)CC[C@H](NCc1ccc(NC(=O)c2cnc3nc(N)nc(O)c3n2)cc1)C(=O)O</smiles>

Figure 4. Synthesis of N4Py-C-C-FA and N4Py-S-S-FA 


\subsection{Arabinogalactan-folic acid-methotrexate conjugate}

Folic acid exibits a high affinity toward the folate receptor (FR). We proposed a new selective delivery mechanism based on the naturally occurring polymer AG for anticancer drugs and characterized their ability to detect, penetrate and kill tumor cells with overexpression of folate receptor [52].

Pinhasi et al., developed a method, in this FR-AG-GFLG-MTX (Folate receptor Arabinogalactan endosomal cleavable peptide of methotrexate) (Figure5) is the conjugate which delivers a cytotoxic agent in FR overexpressing cells. In this conjugate, folic acid and methotrexate are bond to arabinogalactan (AG) via endosomal cleavable peptide (GFLG). The formed conjugate FR-AG-GFLG-MTX shows 6.3-fold increase in the cytotoxic activity. This research produces a new FA bound anticancer agent conjugate to deliver methotrexate to the overexpressed cancer cells in FR [40-42]. An important potential benefit of this drug delivery mechanism is that it exibits effective therapy for malignant cells and multidrug-resistant tumor cells [52, 55].
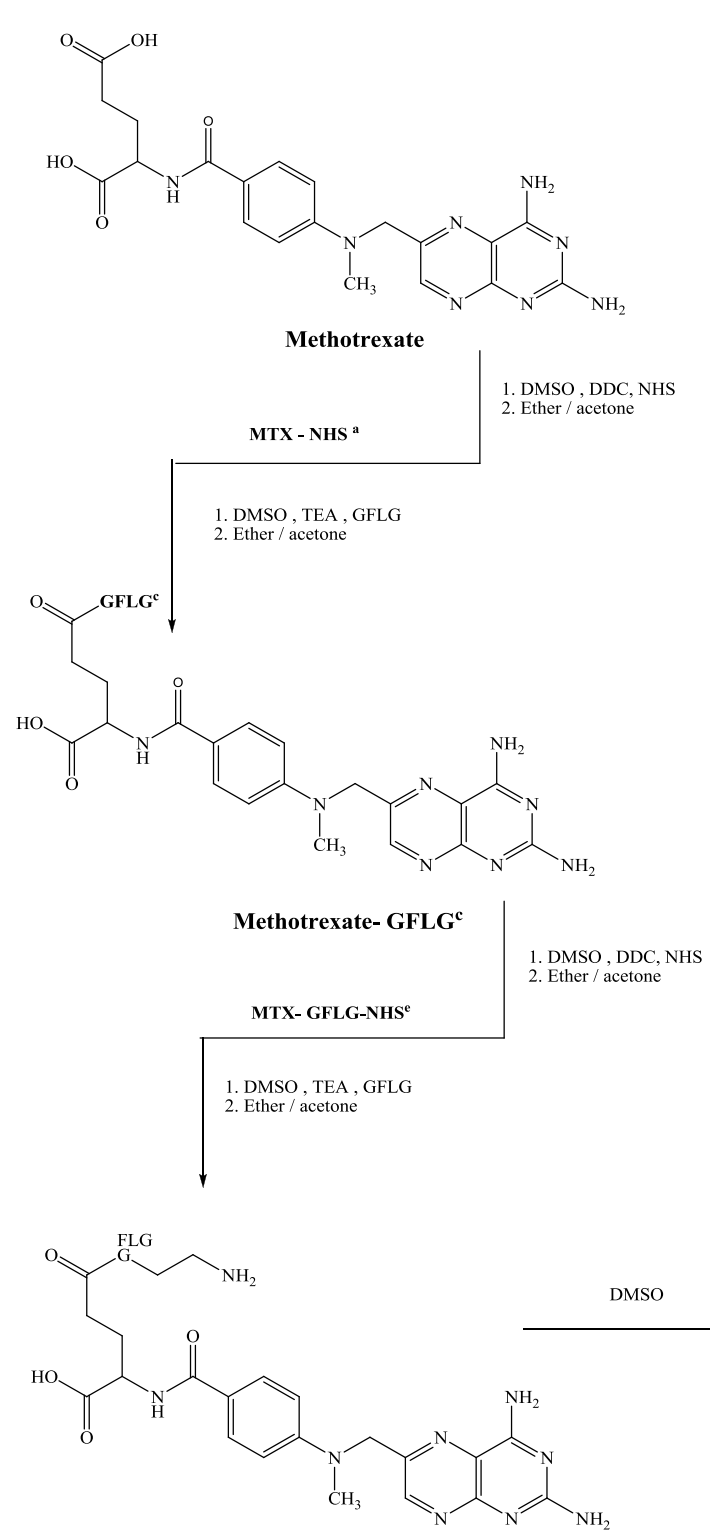

Methotrxate-GFLG-EDA ${ }^{\mathrm{f}}$

a Methotrexate- $N$-hydroxysuccinamid ester b Folic acid- $N$-hydroxysuccinamide ester c Gly-Phe-Leu-Gly

$d$ Folic acid-propane-1,3-diamine

e Methotrexate-Gly-Phe-Leu-Gly-N-hydroxysuccinimide ester

$f$ Methotrexate-Gly-Phe-Leu-Gly-ethyleneamine

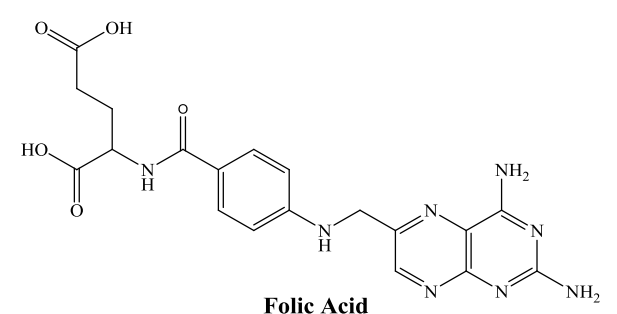

Folic Acid
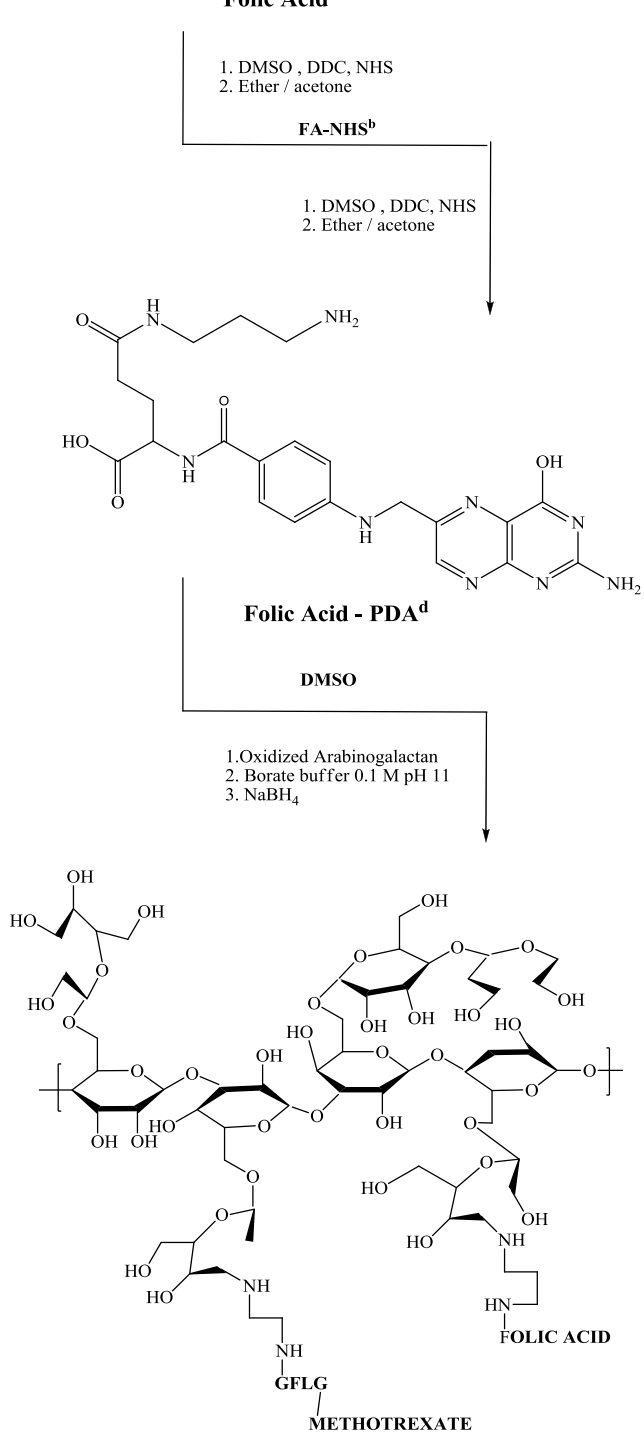

Figure 5. Synthetic scheme of FA-AG-GFLG-MTX Conjugate 


\subsection{Docetaxel loaded -PLGA-PEG Folate conjugated nanoparticles}

Nanoparticulate formulations incorporating anticancer drugs have recently gained much interest due to their accumulation the tumor cells [56, 57]. Esmaeilli et al., reported a method, in which Docetaxel nanoparticles were developed for folate receptor-targeted cancer therapeutics using polylactideco-glycolidepolyethylene glycol-folate (PLGA-PEG-FOL) conjugate (Fig. 6). The FOL-coupled di-block co-polymer was obtained by the reaction of active Folic acid with the co-polymer of the PLGA-PEG-NH $\mathrm{N}_{2}$ di-block, where the folate ligands were supposed to be revealed on the micellar layer. The docetaxel loaded folate conjugate was formed by an emulsification process, with an overall size of $200 \mathrm{~nm}$ in diameter.

In contrast with the non-targeted nanoparticles, the folate targeted ones exibited a higher degree of intracellular absorption via Folate receptor-mediated endocytosis process, which plays an essential role in the absorption of nanoparticles in Folate receptor-positive malignant cells (SKOV3). These studies indicate Docetaxel loaded-folate targeted nanoparticles are a highly beneficial drug delivery system for the tumor cells that are folate receptor-positive and which contribute to increased cytotoxicity [56, 58-60].

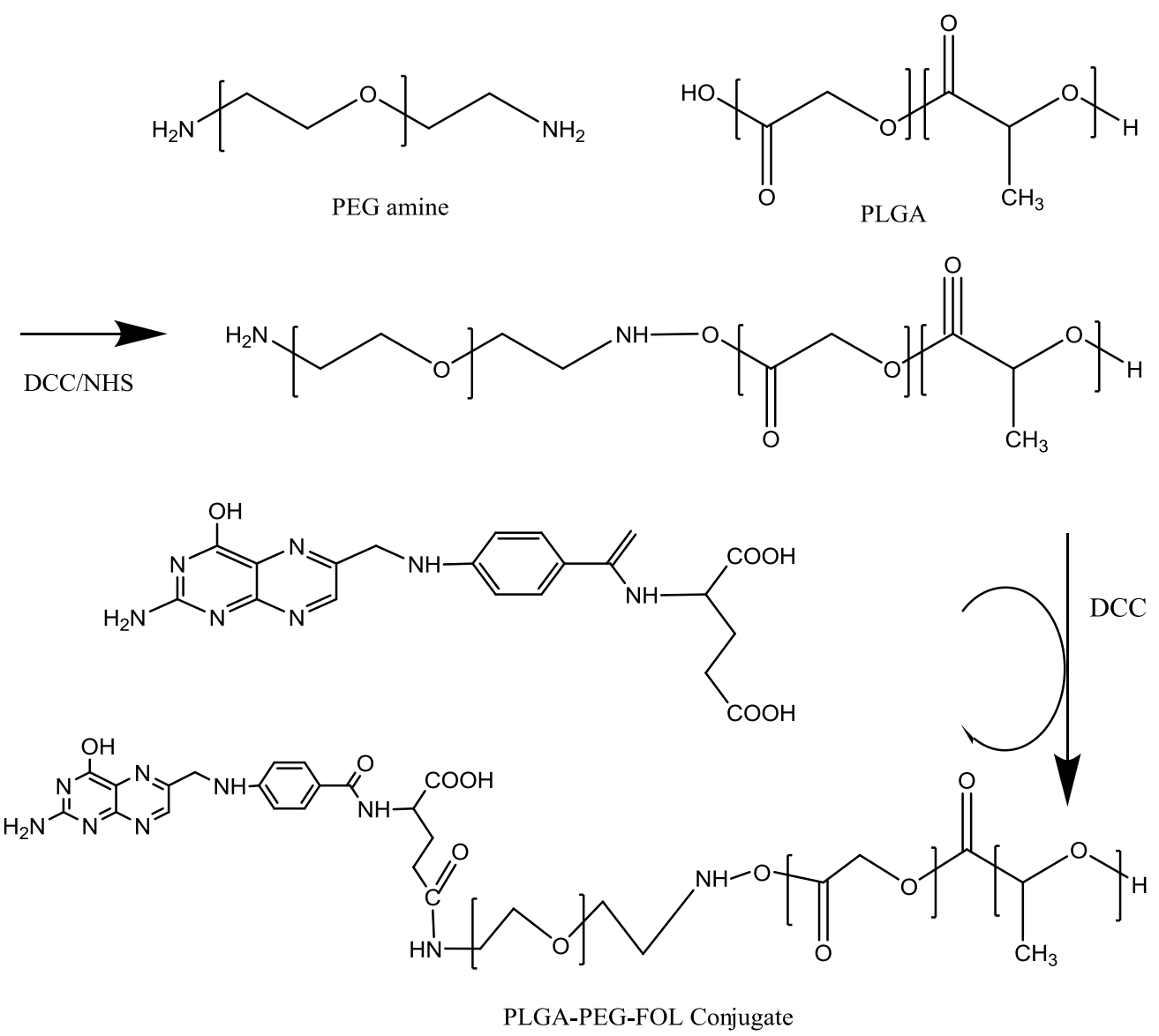

Figure 6. Synthetic scheme of PLGA-PEG-FOL conjugate

\subsection{Folic acid-PEG conjugate}

Folate bond polyethylene glycol (PEG) liposome are obtained for effective cancer therapy because they have an affinity to accumulate into the tumors due to increased permeability [61, 62]. Folic acid phospholipid conjugation (Fig. 7) is the best approach to transfer chemotherapeutic agent to folate receptor (FR) expressing tumor. In this case is used polyethylene glycol (PEG) liposome with folate linked to the outer end of phospholipid attached PEG molecule. It seems to be a suitable way for liposome deposition in tumor and binding of liposome to FR on cancer cells and release anticancer drug via receptor-mediated endocytosis process. [61, 63]. In vitro studies demonstrate that increase in the antitumor activity of liposomal agents occurs via folate targeting in the FR expressing malignant cells [61, 64, 65]. 


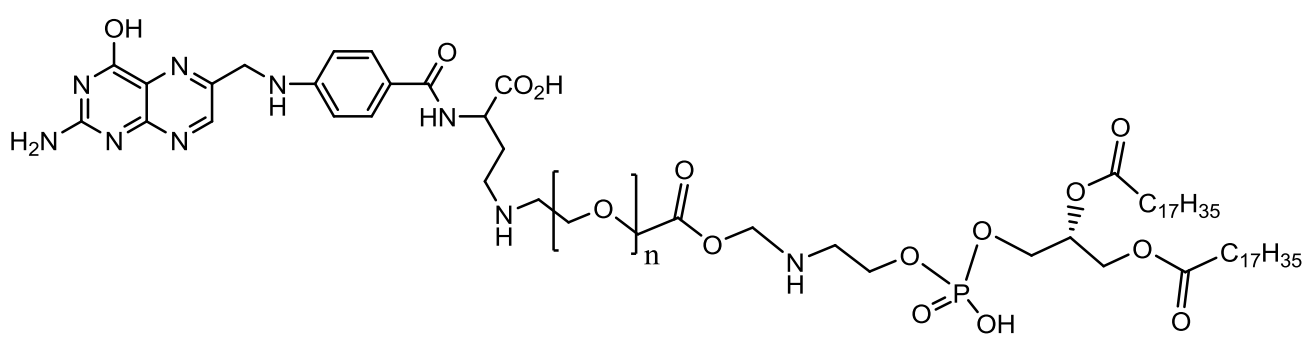

FA-PEG-DSPE

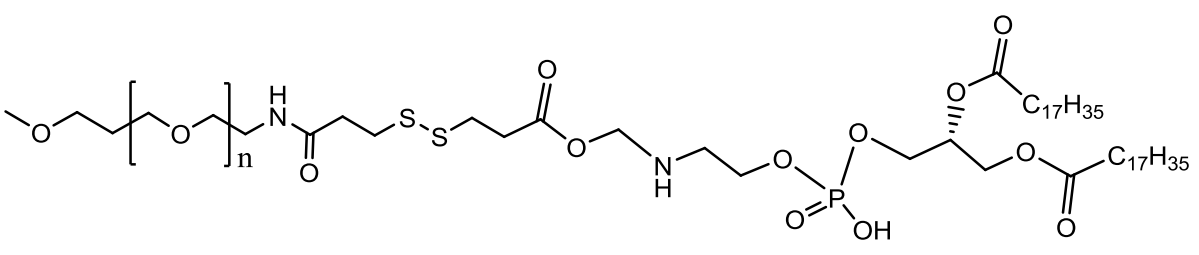

mPEG-DTP-DSPE

Figure 7. Folate-PEG Conjugate

\subsection{Folic acid-5-flurouracil conjugated nanoparticles}

Wanget al., developed a method in which folic acid (FA) shows the low target efficiency, low conjugation ratios at loading as a carrier in PLGA drug delivery system. They used 1,3-diaminopropane as a crosslinker in FA conjugated PLGA system to reach high conjugation ratio of $46.7 \%(\mathrm{~mol} / \mathrm{mol})$. The prepared PLGA (Polylactic-co-glycolic acid) $[66,67]$ was used to encapsulated drug 5-flurouracil (5-HT) into nanoparticles on HT-29, cancer cells were observed to be 5-69 $\mu \mathrm{g} / \mathrm{ml}$ in-vitro. In the experiment the value IC50 is smaller for 5-FU and 5-FU loaded PLGA nanoparticles which is 22.9 and $14.17 \mu \mathrm{g} / \mathrm{mL}$, respectively. The fluorescent microscopy image showed that targeting nanoparticles have a high affinity for cancer cells and nanoparticles with FA. This is more significant amount taken up by cancer cells of HT-29 than the pure drug and untreated nanoparticles. 1,3 di-aminopropane forms a new polymer by facilitating conjugation of FA to PLGA. This FU loaded PLGA-1,3-diaminopropane folic acid nanoparticles (Fig. 8) are one of the efficient approaches to transfer the drug to tumor cells $[66,68,69]$.<smiles>CC(C(=O)C(C)(C)O)C(C)(C)OC(C)(C)C(=O)COC(C)(C)c1ccccc1</smiles>

PLGA<smiles>NCCCN</smiles>

1,3-diaminopropane<smiles>CC(OC(C)(C)NCCCN)C(=O)CC(C)(C)NCCC(C)(C)O</smiles><smiles>Nc1nc(O)c2nc(CNc3ccc(C(=O)NC(CCC(=O)O)C(=O)O)cc3)cnc2n1</smiles> 


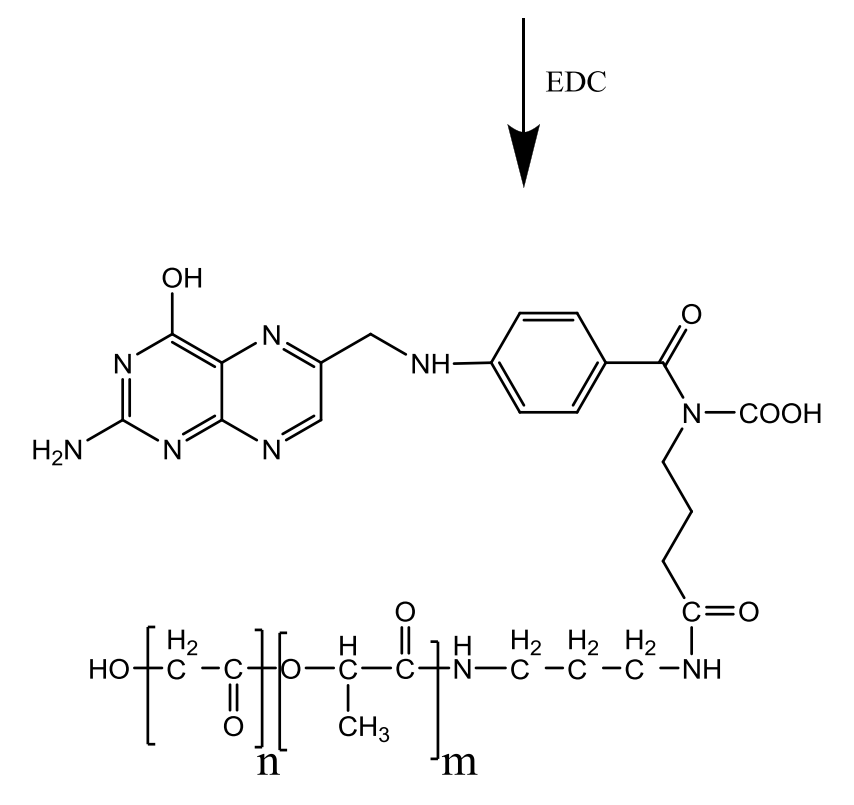

PLGA 1,3-diaminopropane folic acid

Figure 8. Synthetic scheme of PLGA-1,3 diaminopropane-folic acid

\subsection{Guar gum loaded methotrexate-folic acid conjugated nanoparticles}

Prepared nanoparticles have excellent properties for drug delivery, such as small size, including the use of biodegradable polymers, and advantages over other innovative drug delivery systems and provide protection, increased stability. Nanoparticles can easily accumulate into the tumor cells due to their small size and provide effective cancer treatment [70-72].

This nanoparticles are developed to target colon cancer. Sharma et al. developed guar gum nanoparticles (GG-NP) with methotrexate (MTX) loaded folic acid. Emulsion cross-linking methods are used to prepare the MTX charged folic acid biocompatible guar gum nanoparticles. The formed conjugate MTX-FRGGNP shows promising release anticancer drug methotrexate to overexpressed folate receptor and treating colorectal carcinoma. This formulation has dual benefits tend to release the drug in the colon and case of carcinoma $[70,73,74]$

\subsection{Methotrexate-dendrimer-folic acid conjugate}

Thomas et al., demonstrated that conjugating Folic acid and methotrexate with 5 th generation dendrimer [75-77] increases the therapeutic index of Methotrexate (MTX) comparing with methotrexate administered alone $[75,78,79]$. Batch to batch discrepancies in the number of methotrexate (MTX) and folic acid molecules associated with each dendrimer, mainly while scale up processing resulted in differing the therapeutic action of conjugated batches [80, 81].

The biological differences might arise from the enzymatic activity of serum esterase enzyme and result in differences in bioavailability of selected conjugate because methotrexate is bonded through an ester bond $[75,78]$. In this study, they attempted a new methodology to generate specialized G5-MTXn adduct via a selective synthesis process by linking MTX to the pentavalent dendrimer using an esterase-stable amide coupling. Synthesized G5-MTX adduct bind to the folic acid receptor via pentavalent coupling that displays 4300-fold more significant activity than free MTX, it was demonstrated by the results of surface plasmon resonance linking studies. This adducts resist enzyme dihydrofolate reductase and also promote cytotoxic effect in FR-expressing KB cells lines via the FR-specific cellular interaction process and by coupling of MTX with pentavalent dendrimer, which plays a significant role as an anticancer agent and also a targeting molecule. The G5-MTXn adduct acts as a promising FR-selective, cytotoxic agent for the treatment of cancer $[75,78,79,82]$. 


\section{Biotin Drug conjugate}

Biotin is one of the essential vitamins and acts as a promising targeting agent. Vitamin drug conjugate is an approach to deliver a high dose of the targeted drug to cancer cells [83]. Biotin is an essential vitamin and is transported through sodium-dependent multivitamin transporter, which is more expressed in many cancers cell lines like colon, breast, lung cancer cell line. Biotin shows overexpression in folate receptor, so growing tumors more need for biotin than normal cells.

It is reported that the conjugation of biotin with many organic molecules and protein shows selective delivery of a cytotoxic agent to cancer cells [84].

\subsection{Biotin-taxoid conjugate}

Yang et al., developed conjugate in which biotin is combined with new generation taxoids 5BT-1214 [83]. The approach of this invention is simple for tumour-targeted drug delivery system. The use of biotin 5BT-1214 conjugate (Fig. 9) exploits the biotin receptor's upregulation on the cancer cells. The invented process involved the drug delivery via endocytosis mediated by vitamin receptor [16, 83].

The testing result of biotin 5BT-1214 fluorescence conjugate showed the biotin drug conjugate easily incorporate into tumor cell and shows reduced toxicity against normal cells and also shows well systematic stability. Therefore it is one of the best novel targeted drug delivery system for tumor cells [83]. The findings suggest that only the biocompatible biotin-dendrimer adduct may be a successful nano-platform towards cancer treatment and cancer detection [85].

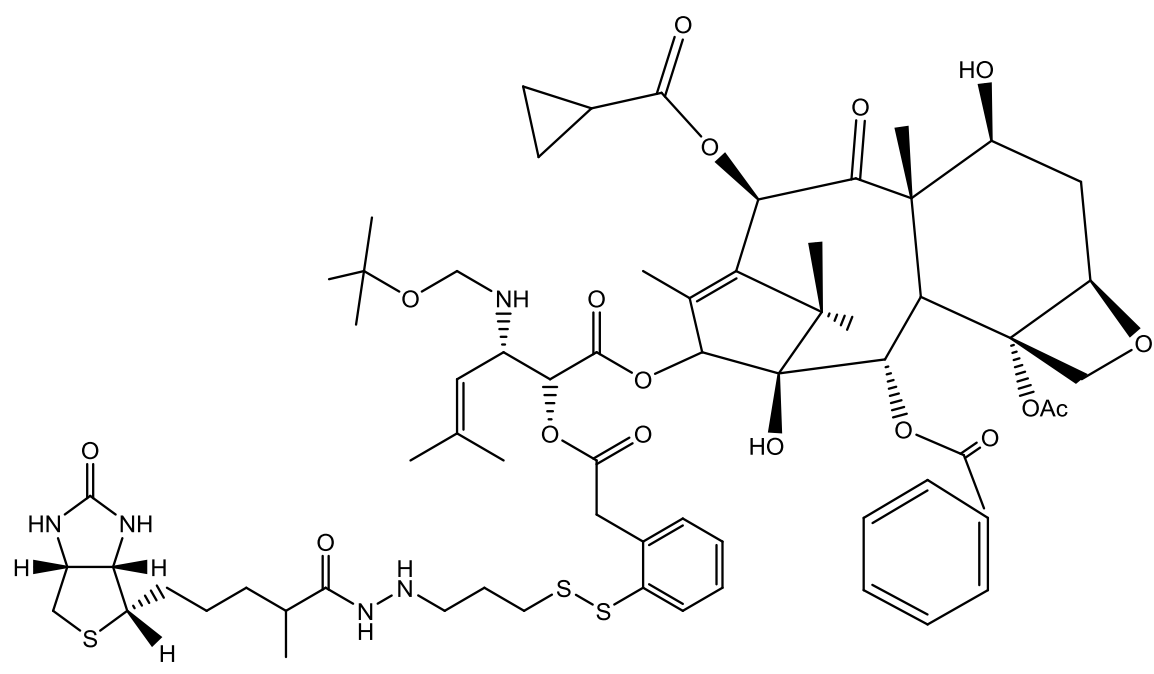

Figure 9. Chemical structure of Biotin-SBT-1214 conjugate

\subsection{Gemcitabine-Coumarin-Biotin conjugate}

Maiti et al., developed target-specific anticancer prodrug moiety Gemcitabine-Coumarin-biotin conjugate (Fig. 10) to treat various cancers $[16,86]$. In this method, they proposed the formulation, development, spectroscopic analysis, and in vitro biological evaluation of Gemcitabine-coumarin-biotin conjugate. This conjugate is a multipurpose molecule mainly consisting of a splittable disulphide bond with a thiol group, fluorescent coumarin moiety, therapeutic action given by gemcitabine and biotin is serve as a cancertargeting component. Breakdown of the disulphide bond occurs when a free thiol group are added, which is exceptionally high in cancerous cells and also release of therapeutic agent gemcitabine, as well as concurrently rise in fluorescence intensity $[86,87]$.

Confocal microscopic studies demonstrate that instead of W138 cells, this scaffold is selectively absorbed by A549 cells. Fluorescence-based colocalization experiments utilizing specific lysosome and endoplasmic reticulum additives indicate that splitting of thiol-containing disulphide bond of the conjugate can occur in the lysosome by receptor-mediated endocytosis process. This is latest approach with a therapeutic and diagnostic tool that provides both therapeutic benefit, and drug absorption at the cellular level is effectively controlled by fluorescence imaging $[86,88,89]$. 


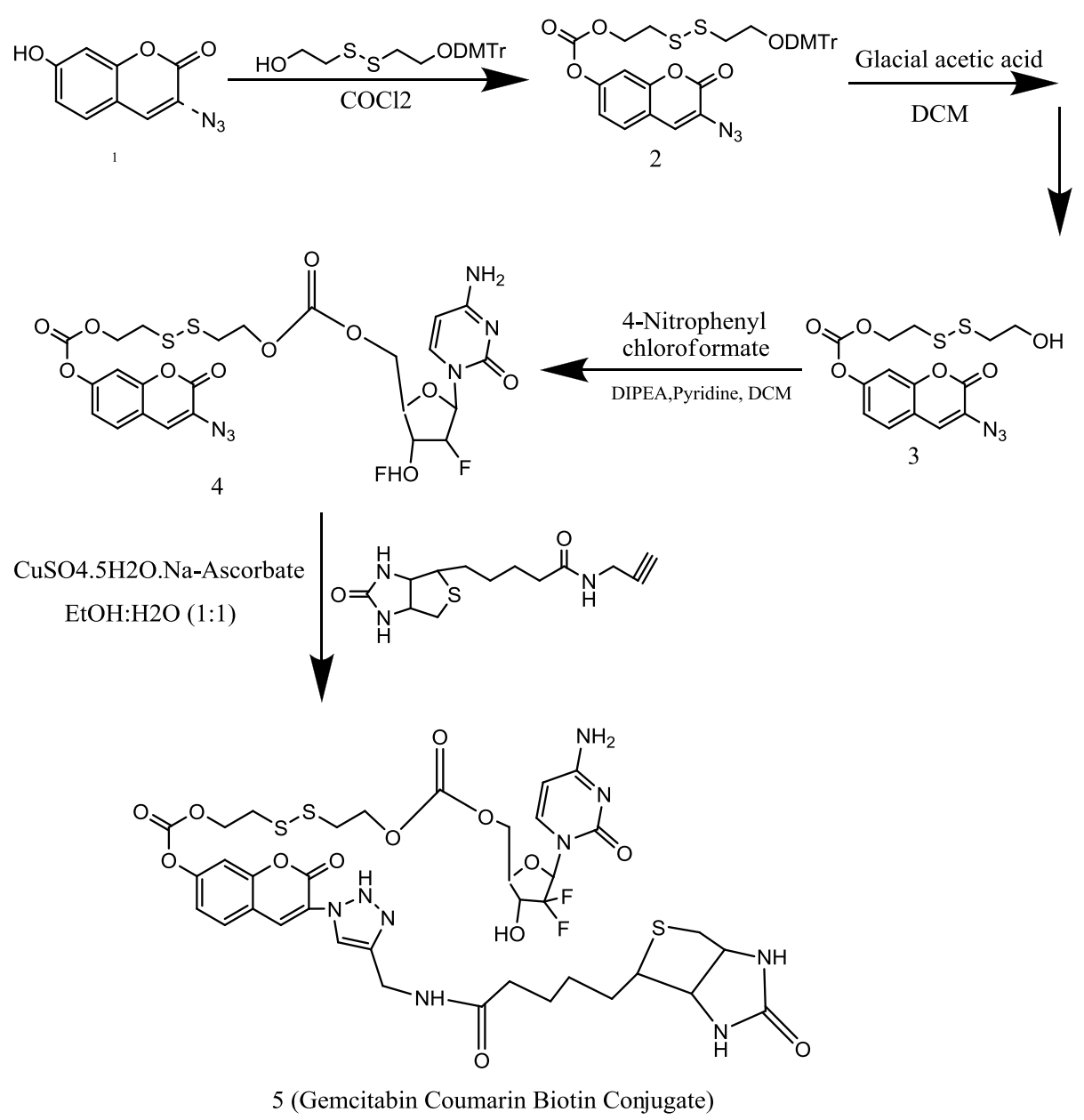

Figure 10. Synthetic scheme of Gemcitabin Coumarin Biotin Conjugate

\section{Vit-E-drug conjugate}

Vitamin-E and $\alpha$-tocopherol analogues have a pro-apoptotic property and can kill cancerous cells, also helps in the prevention of cancer without any undesirable effects [90]. Vitamin-E and tocopherol analogues are used in drug delivery system because of their many excellent advantages like drug solubility, biocompatibility and antitumor activity. Upon esterification of vitamin-E succinate, the formation of non-ionic amphiphile known as $\alpha$-Tocopheryl polyethylene glycol succinate (TPGS) shows the ability to cluster formation behaviour with other organic molecules. Hence it is helpful to develop many drug formulations which show properties like increase bioavailability and targetability of many anticancer drugs [91].

\subsection{Gemcitabine-Vit E Conjugate}

The main aim of this study is to test in vitro anticancer activity of gemcitabine conjugate to the tocotrienol isomer of vitamin-E (Fig. 11) against pancreatic tumor cells [92, 93]. Abu-Fayyad et al., reported that the free tocotrienol isomer of vit $\mathrm{E}$ shows the anticancer activity of gemcitabine. By using $1 \mathrm{H}$ NMR and mass spectrometry analysis technique, the conjugate was identified and tested for deamination sensitivity. The anticancer activity of gemcitabine was studied in vitro for pancreatic cancer cells BX-PC3 and PNAC-1 in which $[92,94]$.

$\gamma$-T3 conjugation of gemcitabine studied in vitro for enzymatic deamination showed that it was least affected comparing with free and conjugated gemcitabine in solution by deamination deactivation reaction. In vitro cytotoxicity studies indicate that an increase of anticancer activity by entrapping gemcitabine lipid conjugate into a nano-emulsion compared to a free drug is observed. It was concluded that for effective delivery of gemcitabine, conjugation with $\gamma$-T3 isomer is one of the feasible options $[92,93,95]$. 
<smiles>Nc1ccn(C2OC(CO)C(O)C2(F)F)c(=O)n1</smiles>

Gemcitabine $\mathrm{HCl}$
Step 1:Synthesis of BOCylated Gemcitabine

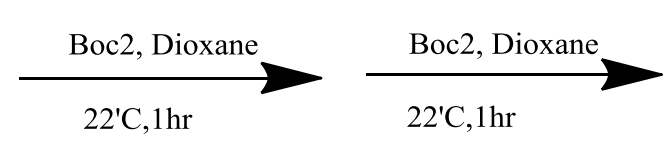

BOCylated Gemcitabine

Step 2: Formation of Gemcitabine-tocotrienol conjugate<smiles>CC(C)=CCC/C(C)=C/CC/C(C)=C/CCC1(C)CCc2cc(O)c(C)c(C)c2O1</smiles><smiles>CC(C)=CCC/C(C)=C/CC/C(C)=C/CCC1(C)CCc2cc(OC(=O)CCC(=O)O)c(C)cc2O1</smiles><smiles>CCCCCC1(CC/C=C(\C)CC/C=C(\C)CCC=C(C)C)CCc2cc(OC(=O)CCC(=O)Cl)c(C)cc2O1</smiles>

?-T3 Succinate Chloride

BOCylated Gemcitabine<smiles>CC1OC(COC(=O)OC(C)(C)C)C(COC(=O)OC(C)(C)C)C1(F)F</smiles><smiles>CC(C)=CCC/C(C)=C/CC/C(C)=C/CCC1(C)CCc2cc(OC(=O)CCC(=O)Nc3ccn(C)c(=O)n3)c(C)cc2O1</smiles><smiles>CC(C)=CCC/C(C)=C/CC/C(C)=C/CCC1(C)CCc2cc(OC(=O)CCC(=O)Nc3ccn(C4OC(CO)C(O)C4(F)F)c(=O)n3)c(C)cc2O1</smiles>

Gemcitabine -T3 conjugate

Figure 11. Synthetic scheme of Gemcitabine Vitamin E (Tocotrienol) Conjugate

\subsection{Ubiquinol-Polyethylene glycol-Vit E conjugate}

Both Ubiquinol and vit E have medicinal value but drawback associated with the Ubiquinol and Vit E, shows low bioavailability, potential toxicity because they have less soluble in aqueous media [96, 97]. Cateniet al., developed a method to overcome the challenge associated with vitamin-E and Ubiquinol. The objective of the present study is to improve the bioavailability of ubiquinol and vit E; the mixed conjugate of Ubiquinol-Polyethylene Glycol-Vitamin E (Fig. 12) was synthesized and characterized. By spectroscopic 
methods such as 1H NMR and mass spectroscopy, the synthesized mix conjugate of PEG was characterized. The in vitro release of the conjugate was calculated and evaluation of ubiquinol and vit $\mathrm{E}$ also carried out in different $\mathrm{pH}$ conditions in human plasma. The obtained result indicates that at $\mathrm{pH} 7.4$. occurs more release of ubiquinol and vit E from PEG conjugate in plasma within $24 \mathrm{hrs}$. The evaluation of antioxidant activity carried out by DPPH assay and obtained results show that there is no effect on antioxidant activity of ubiquinol and vit-E after esterification with PEG.

The novel CoQ10H2-PEG5000-Vitamin E combined conjugate was obtained and observed an enhancement in water solubility of CoQ10, Vitamin E is predicted by this conjugate. The increase of the beneficial effects and reducing the undesirable side effects of the parent products are observed. [96, 98, 99].

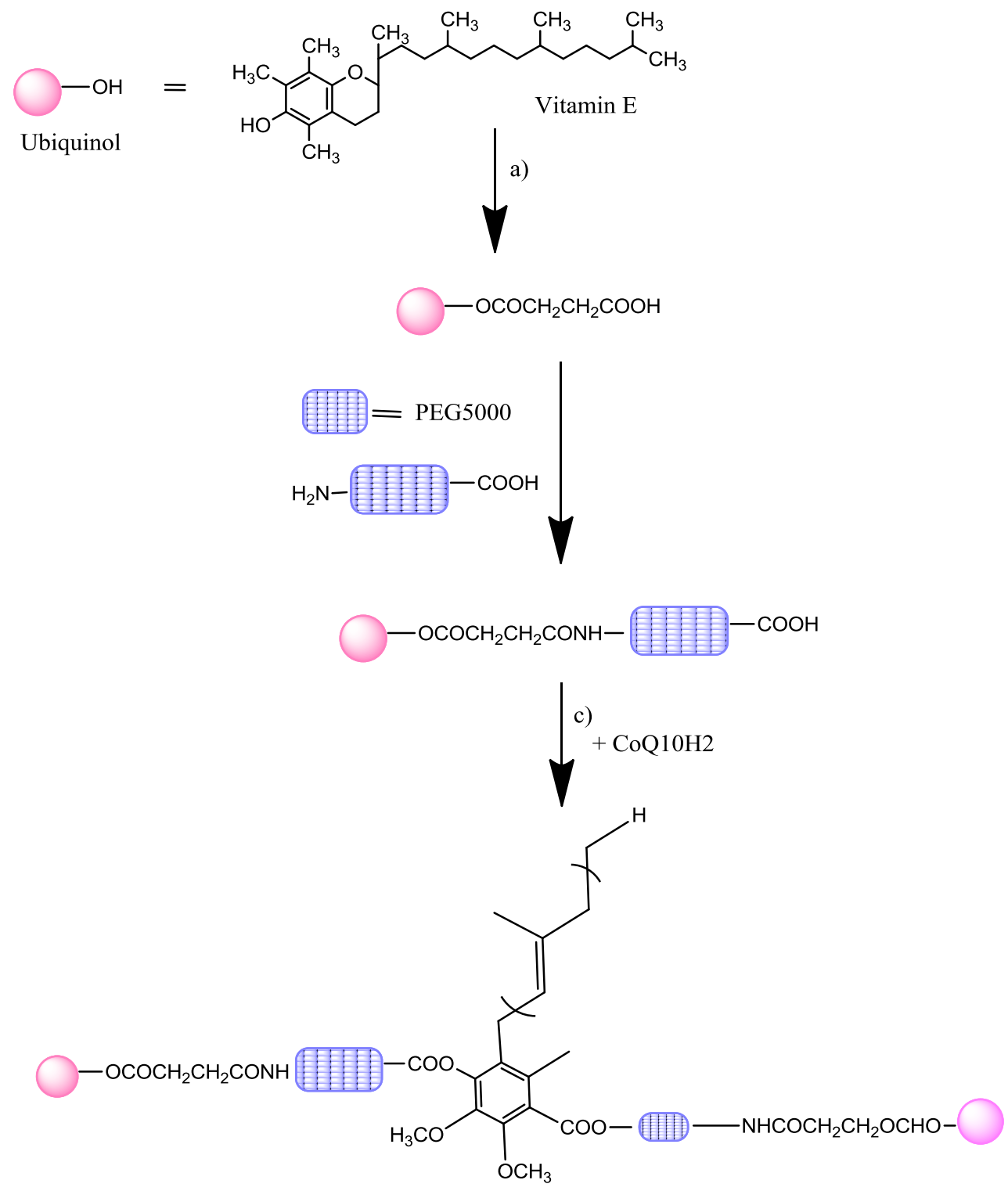

PEGylated derivative of COQ10 and Vit E

a) Succinic anhydride, Toluene Et3N,85?C,9 H; b) Et3N, DCC, HOBT, dry CH2Cl2, Room temperature,24h;c)DCC,DMAP, dry CH2C12, Room temperature, under nitrogen $24 \mathrm{~h}$.

Figure 12. Synthetic scheme of PEGylated Ubiquinol-Vit E conjugate 


\subsection{Vit-E-neomycin conjugate}

Vit E conjugated neomycin derivative (Fig. 13) is a novel approach to deliver siRNA (small interfering RNSs) to liver cells. In this approach the neomycin derivative exibited RNAi (RNA interference) activity in liver cancer cell $[100,101]$.

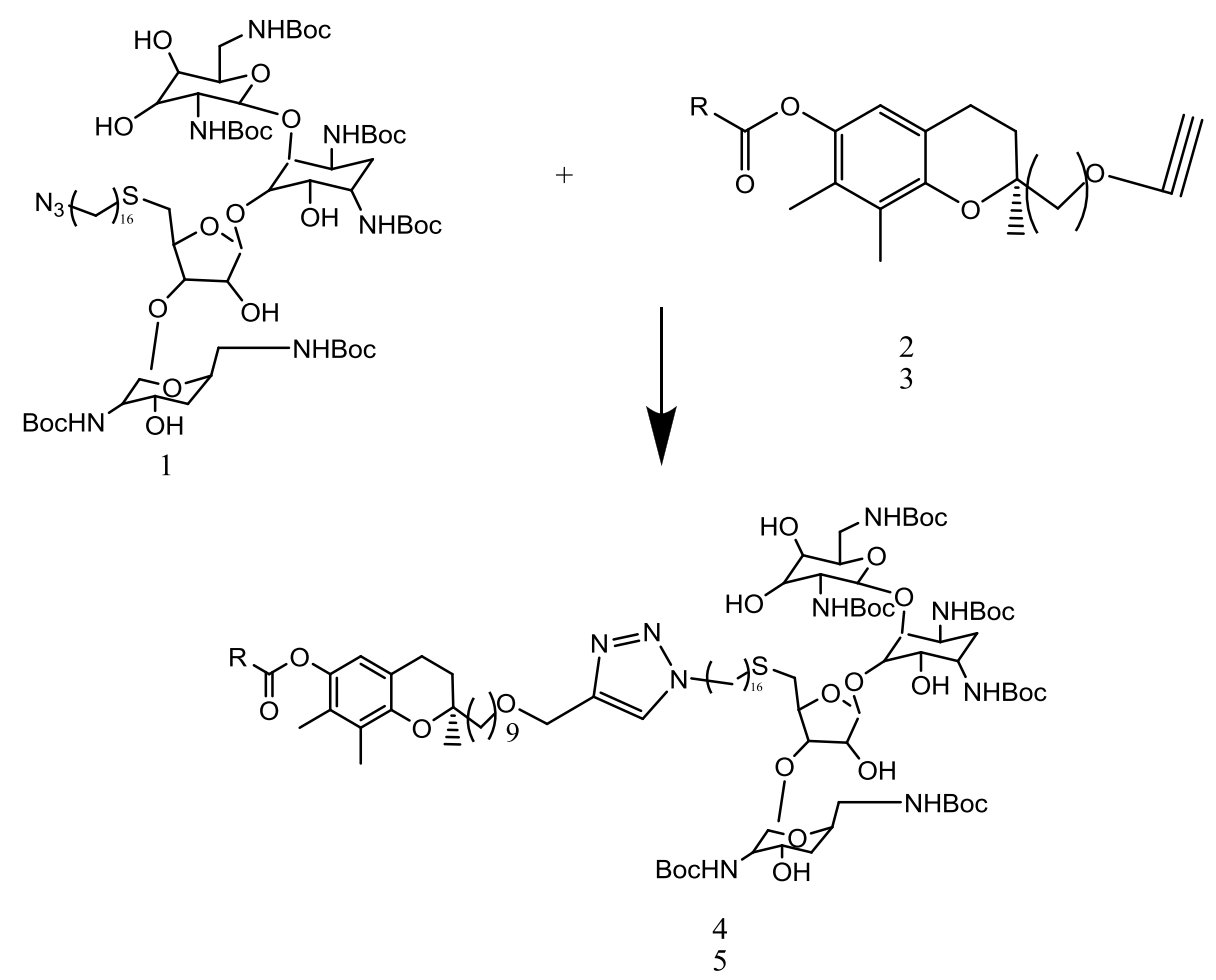

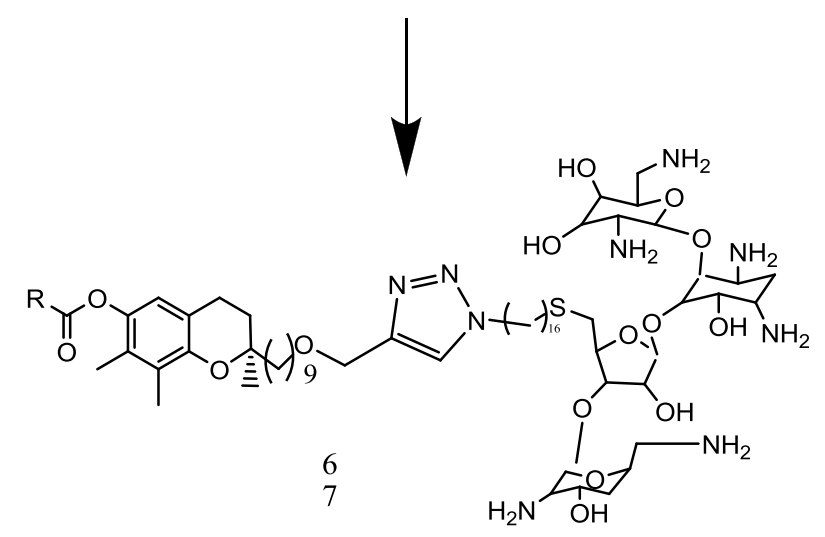

Scheme 1. Synthesis of the prodrug derivatives $6 \& 7$. Reagents and conditions : (a) Cu powder, t-BuOHwater, 80 'C, 4h, 89-97\%, (b)Triisopropylsilane, TFA-CH2Cl2, rt, 1h, 79-92\%

Figure 13. Synthetic scheme of Vit-E-neomycin conjugate

\subsection{Docetaxel loaded Vitamin-E TPGS micelle with cetuximab:}

Kutty et al., and Feng et al., developed docetaxel loaded vitamin E TPGS micelle to treat triple-negative breast cancer. For the selective delivery of docetaxel as a design anticancer drug for the treatment of triplenegative breast cancer (TNBC), produced a Cetuximab-conjugated vitamin E TPGS micelles. Hormone progesterone receptor (PR), estrogen receptor (ER) and epidermal growth factor receptor 2 (HER2) [102, 103] are not expressed, therefore their treatment more challenging than positive breast cancer. In docetaxel loaded vitamin E TPGS micelle cetuximab behaves like as targeting ligand. Vitamin E TPGS micelle is designed 
with small particle size, have more drug loading capacity, also shows excellent drug release pattern. Micelles are characterized by surface appearance, charge. [102, 104].

TNBC cell lines like MDA MB468, MDA MB 231 and HCC 38 cell line with the expression of epidermal growth factor receptor 2 at a high frequency are used. Moderate and low frequencies are used to check in vitro, anticancer activity, as well as cellular absorption of docetaxel, loaded Vit.E TPGS micelles with cetuximab in contrast to a free drug-like Taxotere. The evaluated IC50 value indicates that the therapeutic agent's concentration can kill $50 \%$ of malignant cells in desired time, like $24 \mathrm{hrs}$. By comparing the free drug Taxotere, the IC50 value for the micelle is obtained. Thus it was found that docetaxel loaded vitamin E TPGS micelle exibits a 205.6 and 223.8 fold increase in anticancer activity in TNBC compared to free drug Taxotere $[102,105]$.

\section{Vitamin-C Conjugate}

\subsection{Vitamin C-Saquinavir conjugate (Ascorbyl-succinic-saquinavir)}

Luo et al., and Wang et al., developed the ascorbyl-succinic-saquinavir (Aa-Su-Saq) conjugate (Figure14). It was synthesized and evaluated to target sodium-dependent vitamin-C transporter (SVCT) in order to improve the oral absorption of prodrug saquinavir. The affinity of Aa-Su-Saq regarding efflux pump p-glycoprotein(p-gp) and recognition by SVCT of Aa-Su-Saq have also been studied [106, 108].

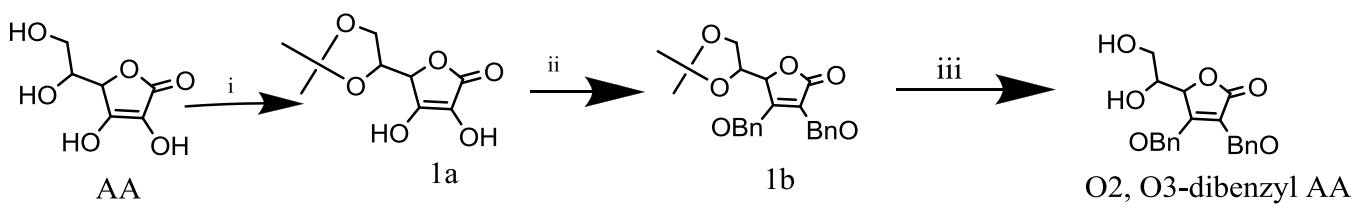

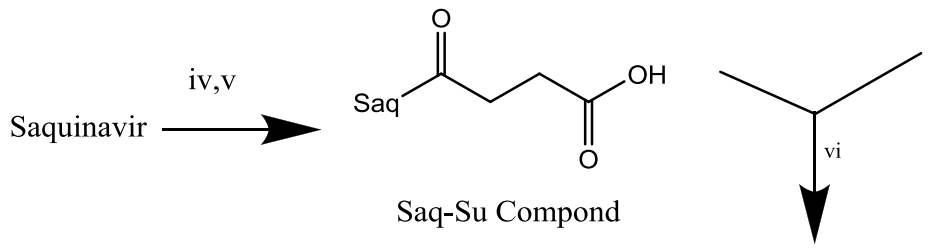

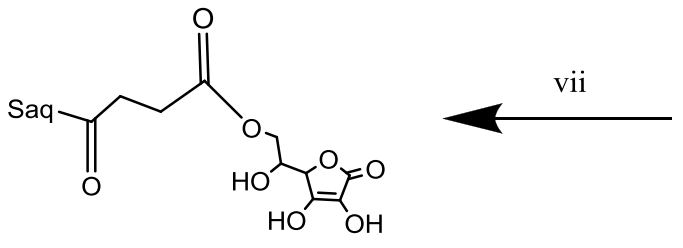

Ascorbic-succinic-saquinavir Conjugate<smiles>O=C([GeH3])CCC(=O)OCC(O)C(OCc1ccccc1)C(=O)OCc1ccccc1</smiles>

Intermediate

i)Acetyl chloride, acetone, 4, RT. ii)K2CO3, Benzyl chloride,DMF'60?C 8 h iii) 50\%acetic acid, methanol, 100?C , 5h, iv)DCC,DMAP, ?-(tert-butyl)Succinic acid,CH2Cl2,24 h, v)TFA, RT,2h vi) DCC, DMAP, CH2Cl2,24 h vii)H2, $10 \%$ Pd/C,THF $24 \mathrm{~h}$

Figure 14. Synthetic scheme of Ascorbic-succinic-saquinavir Conjugate

Polarized MDCK-MDR1 and CaCO-2 cells were taken to determine transepithelial permeability, and rat liver microsomes were used to study the metabolic stability of Aa-Su-Saq. Aa-Su-Saq is stable in DPBS and CaCO-2 cells, having a half-cell life of 9.65 and $5.73 \mathrm{~h}$. In MDCK-MDR1 cells, saquinavir absorption

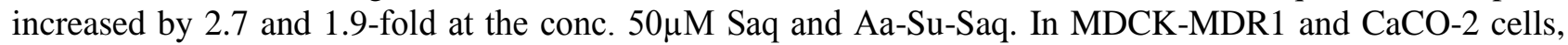
cellular accumulation of AA was decreased by $50-70 \%$ compared to control in the presence of $200 \mu \mathrm{M}$ of Aa-Su-Saq. In the presence of $5 \mathrm{M} \mu$ ascorbic acid, the uptake of AA-Su-Saq was decreased by about $27 \%$ to $34 \%$, and absorptive permeability was increased about 4.5-fold. The efflux index was lowered about 13-15fold in polarized MDCK-MDR and CaCO-2 cells. Aa-Su-Saq not only free from cytotoxicity but also shows an increase in metabolic stability because it shows less affinity toward CYP3A4 [106, 107, 109]. 


\section{Lipid-Drug conjugate \\ 6.1 Stearoyl chloride-Isoniazid conjugate}

Isoniazid is the first line anti-tubercular drug in the treatment of tuberculosis. However, there is some limitation associated with its hydrophilic nature, therefore exibits low permeability and have less affinity to cross blood-brain barrier, which results in the low therapeutic output. This problem can be solved by incorporating hydrophobic moiety of the covalently linked lipid-drug conjugate of Isoniazid with a small lipid chain of stearoyl chloride (Fig. 15). Using the method of cold high-pressure homogenization also improves the bioavailability of Isoniazid; lipid-drug conjugate nanoparticles were produced by using an aqueous surfactant. The physicochemical analytical methods like transmission electron microscopy, differential scanning calorimetry, X-ray diffraction method were applied to characterize nanoparticles. In vitro, drug release studies conclude that at $\mathrm{pH}$ of 7.4, in phosphate buffer solution shows sustained drug release up to $72 \mathrm{hrs}$. Higuchi model of diffusion is an attractive one to study the drug release profile of nanoparticle.

This lipid drug conjugate is effective in mycobacterium tuberculosis infection by intracellular trafficking into endosomal and lysosomal vesicles and colocalization with intracellular protein like CD63, LAMP-2, EEA1 and Rab11. These nanoparticles exibit affinity to improve effective intracellular absorption of watersoluble drug Isoniazid $[110,111]$.
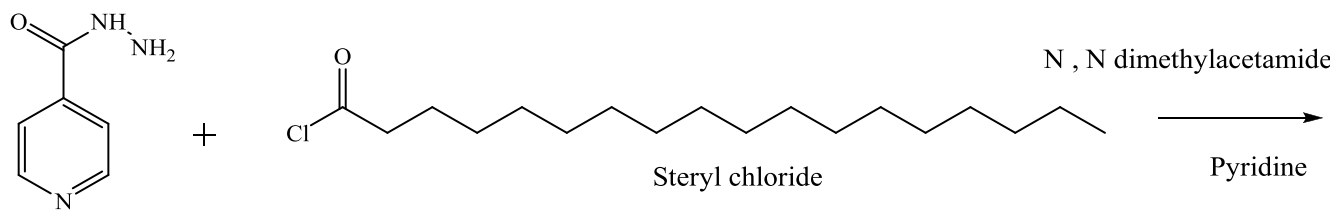

Isoniazid

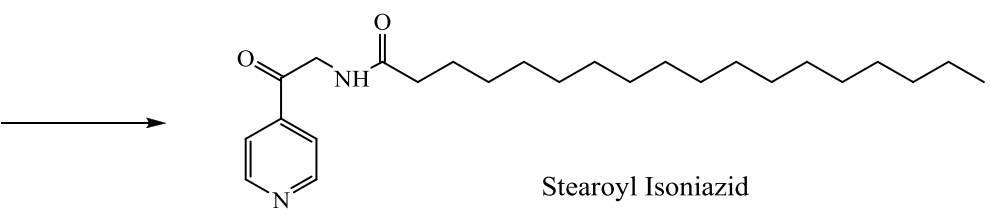

Figure 15. Synthesis of Isoniazid- Stearoyl chloride conjugate

Other approaches for the treatment of cancer and other diseases

\section{Polymer drug conjugate}

Cancer is considered as chronic illness which responsible for the elevated mortality rate in the world. The effective treatment for the cancer illness is the administration of the chemotherapeutic agent, even though its clinical status is not acceptable. The use of antitumor agent is minimal because it may cause serious complication. Therefore, to protect the normal cells from the severe side effects associated with a chemotherapeutic agent, «Polymer-Drug conjugate» is synthesized.

«Polymer-Drug conjugate» is a drug carrier system that consists of three components like a molecular targeting moiety, solubilizing moiety and active ingredient. Polymer-Drug conjugate in which the active drug is incorporated into the polymeric material. Polymer-Drug conjugate is also regarded as polymeric prodrug [112-114].

\subsection{Methotrexate-Poly(glycerol-adipate) conjugate}

Polymer drug conjugate is specially designed and intended for cancer therapy. The present study mentions the first polymer-antitumor drug conjugate obtained by cobination of poly-(glycerol adipate) with antitumor agent Methotrexate (Fig. 16). By using carbodiimide mediated reaction, MTX-PGA complex was developed with the reproducible result and with different high MTX molar concentration; the MTX-PGA adduct is self-build into size nanoparticles. The size of the nanoparticles depends on medium $\mathrm{pH}$ and the quantity of methotrexate. The change of particle size of NPs resulted in stearic hindrance and build bulkiness within nanoparticles centre and separation of the free functional group of the active agent.

MTX-PGA nanoparticles exibit stability at ionic strength equivalent to $0.15 \mathrm{M} \mathrm{HCl}$, in the medium having $\mathrm{pH}$ 5-9. They also show chemical stability at $\mathrm{pH} 7.4$ in case of hydrolysis for 30 days, even though it 
undergoes enzymatic degradation and release of free drug in unchanged form. In comparison with MTXPEA NP, earlier reported studies indicated that by conjugating MTX with serum albumin exhibits > 300 times less potent than pure MTX. But MTX-PEA nanoparticles are slightly potent than free MTX in 791T. Along with the studies on enzymatic degradation, these results show that a linker moiety is not a necessary element with a useful biodegradable polymer. Therefore, these quickly produced PGA drug conjugates without a linker moiety can be a practical new approach for polymer-drug conjugate growth [115].

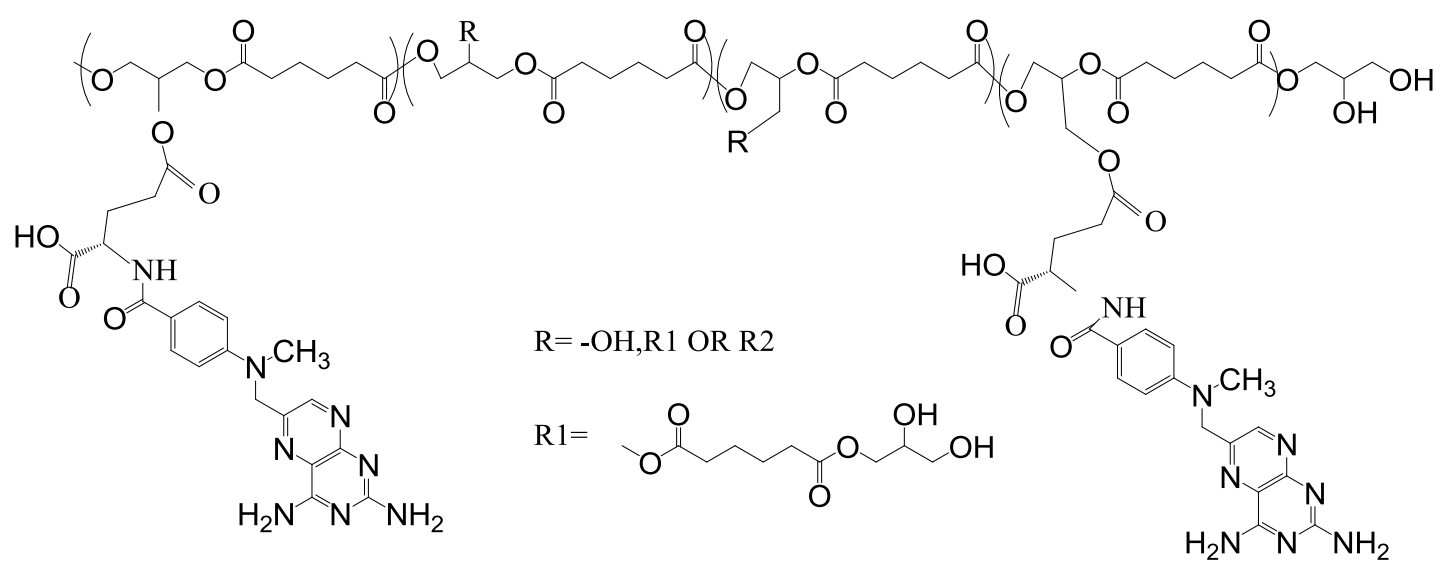<smiles>[R2]OC(=O)CC[C@H](NC(=O)c1ccc(N(C)Cc2cnc3nc(N)nc(N)c3n2)cc1)C(=O)O</smiles>

Figure 16. Methotrexate-Poly(glycerol adipate) conjugate

\subsection{Docetaxel loaded polymeric nanoparticles}

In this study, the drug is conjugated with a polymer producing polymeric nanoparticles to overcome obstacles associated with chemotherapy.

Docetaxel loaded trans-retinoic acid with poly- $\beta$-amino ester (ATRA-g-PBEA) nanoparticles is produced by encapsulation. Docetaxel is conjugated with trans-retinoic acid(ATRA) with poly- $\beta$-amino ester by the solvent displacement method. Using Zeta-sizer, the size and zeta potential of nanoparticles were meas-

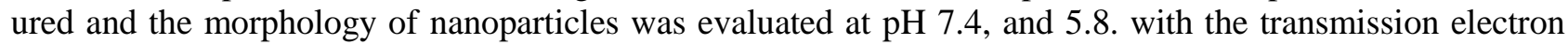
microscopy. The in-vitro drug release study was studied. The cytotoxicity, anti-angiogenic effect and blood compatibility of this controlled release nanoparticles, also studied. The DTX loaded ATRA-g-DBAC nanoparticles show more cytotoxicity and better anti-angiogenic effect compared to free all trans-retinoic acid and docetaxel in chemotherapy. ATRA-g-PBAE nanoparticles are an attractive controlled released system compared to chemotherapy [116].

\subsection{HPMA co-polymer-Dexamethasone conjugate}

Liu et al., and Quan et al., developed pH-sensitive conjugate of N-(2-Hydroxypropyl) methyl acrylamide (HPMA) containing Dexamethasone polymeric conjugate is able to strengthen the therapy of rheumatoid arthritis. Reversible addition-fragmentation transfer (RAFT) polymerization technique is used to create an unique $\mathrm{pH}$-sensitive and cross-linked Dexamethasone-containing monomer (MA-Gly-Gly-NHN=Dex) with HPMA. The scaffold of Dex-HPMA co-polymer conjugate was studied as well as its biological effectiveness was also tested on rodents with adjuvant-induced arthritis (AIA). Polymeric Dexamethasone conjugate was obtained with poly-dispersity index and with controlled molecular weight. Dexamethasone containing monomer (MA-Gly-Gly-NHN=Dex) regulates feed-in proportion ration Dexamethasone material.

The molecular weight of polymeric Dexamethasone conjugate is $34 \mathrm{KDa}$ and PDI is 1.34. at in vivo and in vitro assessment. The release of Dexamethasone from conjugate is caused due to low $\mathrm{pH}$; it is demonstrated by in vitro drug release tests. Polymeric Dexamethasone conjugate has a significant and lengthy antiinflammatory effect and joint safety. These properties are revealed by the tests such as, endpoint bone miner- 
al density and histology grading. Conjugate of Dexamethasone-HPMA co-polymer is obtained with a very well structure is effective against rheumatoid arthritis. In the treatment of rheumatoid arthritis, it also has a specific therapeutic potential [117].

\section{Conclusions}

Chemotherapy is the golden method to treat a chronic disease like cancer, but there is some complication associated with chemotherapeutic agents causing undesirable side effects with systemic toxicity to the normal cells. Therefore, to avoid this problem, a new approach called «vitamin-drug conjugate» is developed. Many research studies reported various vitamin-drug conjugate like folic acid conjugate, Vitamin B12 conjugate, vitamin-C conjugate, vitamin-E conjugate, Biotin drug conjugate etc. In the case of Lipid drug conjugate, many drugs cannot cross the blood-brain barrier due to their hydrophilic nature. Thus, this problem can be solved by combining hydrophilic drug with short-chain of lipid resulting in new adduct is known as «Lipid-Drug conjugate».

The review describes vitamin drug conjugate which is the newly emerged concept for targeted drug delivery to the cancer cells with achieving desirable clinical output. The recent studies revealed that cancer cells are more overexpressed to vitamins than normal cells, so using the method receptor-mediated endocytosis system can deliver a cytotoxic agent to the cancer cells and may not harm any normal cells. To strengthen this concept, many approaches were studied like conjugation with metals, conjugation with gums and conjugation with vitamins etc. Metal drug conjugate is the clinically approved method as it can deliver both therapeutic and diagnostic agents to the cancer cells with a fewer side effect.

Vit.B12 conjugate, in this cobalamin, is covalently bound to the anticancer drug and produce high biological activity. Therefore the conjugation of drug with vitamin exibits high efficacy and low systemic toxicity. In folic acid conjugate, folate receptor is highly overexpressed on cancer cells compared to normal cells. Thus selective drug delivery of cytotoxic agent toward malignant cells can be achieved by binding with folic acid. That is why it is one of the promising methods that have the potential to treat a variety of cancers in future. $\alpha$-Tocopherol polyethene glycol succinate is an ester form of vitamin E succinate that shows excellent properties like increase selectivity as well as bioavailability of anticancer drugs. Another preparations like biotin conjugate, Vitamin-C conjugate and vitamin-A conjugate also proved to be useful in cancer therapy and reducing the toxicity. The folic acid drug conjugate was found to be most active and pharmacologically effective amongst all the other conjugates for the treatment of cancer.

Few challenges may arise associated with vitamin drug conjugate, as a synthesis of the conjugate in cobalamin drug conjugate and biotin drug conjugate. Vitamin B12- metal conjugate shows accumulation in non-targeted organs and leads to a severe undesirable side effect. Thus, it is nessessary to design such conjugate that shows increased uptake and selectivity toward tumor in order to avoid accumulation in organs.

Tuberculosis infection treatment drugs develop multidrug resistance due to the more extended treatment period. This problem can be resolved using vitamin as a target molecule to stop the spread of tuberculosis infection. In addition to anti-tubercular therapy, the newer drug is conjugating with vitamins like vitamin-C and vitamin-D are useful and one of the novels approaches against tuberculosis infection in the future.

In future vitamin drug conjugate is an attractive approach of targeted preparation delivery to the many life-threatening disease like cancer, tuberculosis etc.

The summary of these methods and its advantage are shown in the Table.

$\mathrm{T}$ a ble

Vitamin drug Conjugates

\begin{tabular}{|c|c|c|}
\hline $\begin{array}{l}\text { Sr. } \\
\text { No }\end{array}$ & Vitamin Drug Conjugate & Advantages \\
\hline 1 & 2 & 3 \\
\hline 1 & $\begin{array}{l}\text { Vitamin B12-Metallodrug } \\
\text { conjugate }\end{array}$ & $\begin{array}{l}\text { - Vitamin B12-Metal conjugate can overcome the problems associated with anti- } \\
\text { cancer agents. } \\
\text { - The increase in tumor selectivity and enhance clinical output by conjugating metal } \\
\text { with cobalamin. } \\
\text { - In vitro cytotoxicity experiments carried out on adenocarcinoma cells of human } \\
\text { ovary and human breast cells demonstrated that Pt-II Cyano complex exhibit anti- } \\
\text { tumor activity and quickly release antitumor drug in the body. }\end{array}$ \\
\hline
\end{tabular}


Continuation of Table

\begin{tabular}{|c|c|c|}
\hline 1 & 2 & 3 \\
\hline 2 & $\begin{array}{l}\text { Colchicine- cobalamin } \\
\text { conjugate }\end{array}$ & $\begin{array}{l}\text { - This scaffold is effective against variety of cancers like brain, breast and melano- } \\
\text { ma. } \\
\text { - Colchicine-cobalamin conjugate is one feasible option to resolve the problem as- } \\
\text { sociated with tubulin targeted anticancer drug. }\end{array}$ \\
\hline 3 & $\begin{array}{l}\text { Folic acid-Bleomycin } \\
\text { conjugate }\end{array}$ & $\begin{array}{l}\text { - This conjugate increase potency as well as selectivity of anticancer agents into } \\
\text { tumor cells which over expressed toward folate receptor. }\end{array}$ \\
\hline 4 & $\begin{array}{l}\text { Arabinogalactan-folic acid- } \\
\text { methotrexate conjugate }\end{array}$ & $\begin{array}{l}\text { - Folate targeted arabinogalactan linked methotrexate adduct shows } 6 \text {-3-fold in- } \\
\text { crease in cytotoxic activity as well selective delivery of antitumor agent into the } \\
\text { cancerous cells. }\end{array}$ \\
\hline 5 & $\begin{array}{l}\text { Guar gum loaded metho- } \\
\text { trexate-folic acid conjugated } \\
\text { nanoparticles }\end{array}$ & $\begin{array}{l}\text { - These nanoparticles were designed to target colon cancer. } \\
\text { - Guar gum loaded methotrexate-folic acid nanoparticles play dual function, it pro- } \\
\text { vides robust treatment against the colorectal carcinoma and also show efficacy in } \\
\text { case of another carcinoma. }\end{array}$ \\
\hline 6 & $\begin{array}{l}\text { Methotrexate-dendrimer- } \\
\text { folic acid conjugate }\end{array}$ & $\begin{array}{l}\text { - The coupling of methotrexates with } 5 \text { th generation dendrimer result in increase of } \\
\text { methotrexate therapeutic index comparing to free methotrexate. } \\
\text { - This conjugate is not affected by serum esterase enzyme activity because it syn- } \\
\text { thesized by esterase stable amide coupling, so this adduct exibits } 4300 \text {-fold greater } \\
\text { biological activity in contrast with free methotrexate. }\end{array}$ \\
\hline 7 & $\begin{array}{l}\text { Docetaxel loaded -PLGA- } \\
\text { PEG Folate conjugated na- } \\
\text { noparticles }\end{array}$ & $\begin{array}{l}\text { - Folate targeted docetaxel loaded NPs shows displayed a higher degree of intracel- } \\
\text { lular absorption in Folate receptor-positive malignant cells (SKOV3). }\end{array}$ \\
\hline 8 & Folic acid-PEG conjugate & $\begin{array}{l}\text { - It is novel approach to deliver anticancer agent to cancerous cells by conjugating } \\
\text { folic acid to phospholipid. } \\
\text { - Via folate targeted drug delivery system can be increased anticancer activity of } \\
\text { liposomal active agent in FR expressing cancerous cells. }\end{array}$ \\
\hline 9 & $\begin{array}{l}\text { Folic acid-5-fluorouracil } \\
\text { conjugated nanoparticles }\end{array}$ & $\begin{array}{l}\text {-5-FU conjugated nanoparticles have high affinity toward malignant cells HT-29 } \\
\text { compared to pure drug and display the excellent anticancer activity in the 5-HT } \\
\text { cells, it is demonstrated by florescent microscopy. }\end{array}$ \\
\hline 10 & axoid cc & $\begin{array}{l}\text { - Biotin conjugated with taxoid 5BT-1214, this scaffold is easily integrated into } \\
\text { tumor cells and reduce the cytotoxicity of the normal healthy cells. So, it is novel } \\
\text { approach and targeted drug delivery of cytotoxic agent to the tumor cells. }\end{array}$ \\
\hline 11 & $\begin{array}{l}\text { abine-Cou } \\
\text { onjugate }\end{array}$ & $\begin{array}{l}\text { - This conjugate is multipurpose molecule, which selectively absorbed by the can- } \\
\text { cerous cells A549 instead of W138 cells. } \\
\text { - This multipurpose scaffold provides both therapeutic benefit and also drug absorp- } \\
\text { tion at the cellular level in malignant tumors. }\end{array}$ \\
\hline 12 & $\begin{array}{l}\text { nol-Polyethylene } \\
\text { Vit E conjugate }\end{array}$ & $\begin{array}{l}\text { - Ubiquinol-PEG-Vit.E conjugate resolved the problem associated with ubiquinol } \\
\text { and vit.E like poor bioavailability, potential toxicity. } \\
\text { - In vitro study carried out at different } \mathrm{pH} \text { conditions in human plasma obtained } \\
\text { results revealed that at pH } 7.4 \text { there is more release of ubiquinol and Vitamin-E } \\
\text { from PEG conjugate in plasma within } 24 \mathrm{hrs} \text {. }\end{array}$ \\
\hline 13 & $\begin{array}{l}\text { Gemcitabine-vita } \\
\text { conjugate }\end{array}$ & $\begin{array}{l}\text { - In-vitro studies demonstrate that by conjugating gemcitabine with vit.E which is } \\
\text { least affected by deamination deactivation reaction compared to free drug. } \\
\text { - In-vitro cytotoxicity studies revealed that increase of anticancer activity by en- } \\
\text { trapping gemcitabine in lipid conjugate compared to free drug is observed. }\end{array}$ \\
\hline 14 & $\begin{array}{l}\text { Docetaxel loaded vit-E } \\
\text { TPGS micelle with } \\
\text { cetuximab }\end{array}$ & $\begin{array}{l}\text { - DTX-loaded vit-E TPGS micelle have small particle size, have high drug loading } \\
\text { capacity and excellent drug release pattern. } \\
\text { - The TNBC cell lines like MDA-MB468, MDA MB } 231 \text { and HCC } 38 \text { cell line } \\
\text { have been used to check in vitro activity and was found that docetaxel loaded vit- } \\
\text { amin-E TPGS micelle shows } 205.6 \text { and } 223.8 \text {-fold increase in anticancer activity } \\
\text { in TNBC cell line compared to free drug Taxotere. }\end{array}$ \\
\hline 15 & $\begin{array}{l}\text { Vitamin-C - Saquinavir } \\
\text { conjugate (Aa-Suc-Saq) }\end{array}$ & $\begin{array}{l}\text { - In MDCK-MDR1 cells the absorption permeability of saquinavir is increased } \\
\text { about 4-5-fold from Aa-Suc-Saq conjugate. } \\
\text { - Aa-Suc-Saq conjugate is free from cytotoxicity and show excellent metabolic sta- } \\
\text { bility because it shows less affinity toward CYP314. }\end{array}$ \\
\hline 16 & $\begin{array}{l}\text { Stearoyl chloride -Isoniazid } \\
\text { conjugate }\end{array}$ & $\begin{array}{l}\text { - Isoniazid-stearoyl chloride conjugate is effective in tuberculosis infection, by in- } \\
\text { tracellular transfer into endosomal and lysosomal vesicles. } \\
\text { - The addition of hydrophilic drug isoniazid to short lipid chain stearoyl chloride } \\
\text { result into increase of Isoniazid's bioavailability. }\end{array}$ \\
\hline
\end{tabular}




\section{References}

1 https://www.medicinenet.com/cancer/defination.com

2 Allen, T.M. (2002). Ligand-targeted therapeutics in anticancer therapy. Nature Reviews Cancer, 2(10), 750-763. https://doi.org/10.1038/nrc903

3 Chari, R.V.J. (1998). Targeted delivery of chemotherapeutics: Tumor-activated prodrug therapy. Advanced Drug Delivery Reviews, 31(1), 89-104. https://doi.org/10.1016/S0169-409X(97)00095-1

4 Ojima, I., Geng, X., Wu, X., Qu, C., Borella, C.P., \& Xie, H.et al. (2002). Tumor-Specific Novel Taxoid-Monoclonal Antibody Conjugates. Journal of Medicinal Chemistry, 45(26), 5620-5623. https://doi.org/10.1021/jm025540g

5 Jaracz, S., Chen, J., Kuznetsova, L. V., \& Ojima, I. (2005). Recent advances in tumor-targeting anticancer drug conjugates. Bioorganic \& Medicinal Chemistry, 13(17), 5043-5054. https://doi.org/10.1016/j.bmc.2005.04.084

6 Yan, Y., Dong, Y., Yue, S., Qiu, X., Sun, H., \& Zhong, Z. (2019). Dually Active Targeting Nanomedicines Based on a Direct Conjugate of Two Purely Natural Ligands for Potent Chemotherapy of Ovarian Tumors. ACS Applied Materials \& Interfaces, 11(50), 46548-46557. https://doi.org/10.1021/acsami.9b17223

7 Zhong, Y., Meng, F., Deng, C., \& Zhong, Z. (2014). Ligand-Directed Active Tumor-Targeting Polymeric Nanoparticles for Cancer Chemotherapy. Biomacromolecules, 15(6), 1955-1969. https://doi.org/10.1021/bm5003009

8 Zagami, R., Rapozzi, V., Piperno, A., Scala, A., Triolo, C., \& Trapani, M.et al. (2019). Folate-Decorated Amphiphilic Cyclodextrins as Cell-Targeted Nanophototherapeutics. Biomacromolecules, 20(7), 2530-2544. https://doi.org/10.1021/acs.biomac.9b00306

9 Sun, H., Dong, Y., Feijen, J., \& Zhong, Z. (2018). Peptide-decorated polymeric nanomedicines for precision cancer therapy. Journal of Controlled Release, 290, 11-27. https://doi.org/10.1016/j.jconrel.2018.09.029

10 Jiang, Z., Guan, J., Qian, J., \& Zhan, C. (2019). Peptide ligand-mediated targeted drug delivery of nanomedicines. Biomaterials Science, 7(2), 461-471. https://doi.org/10.1039/C8BM01340C

11 Srinivasarao, M., Galliford, C.V., \& Low, P.S. (2015). Principles in the design of ligand-targeted cancer therapeutics and imaging agents. Nature Reviews Drug Discovery, 14(3), 203-219. https://doi.org/10.1038/nrd4519

12 Srinivasarao, M., \& Low, P.S. (2017, September 12). Ligand-Targeted Drug Delivery (world) [Review-article]. American Chemical Society. https://doi.org/10.1021/acs.chemrev.7b00013

13 Muro, S. (2012). Challenges in design and characterization of ligand-targeted drug delivery systems. Journal of Controlled Release, 164(2), 125-137. https://doi.org/10.1016/j.jconrel.2012.05.052

14 Ojima, I. (2008). Guided Molecular Missiles for Tumor-Targeting Chemotherapy - Case Studies Using the SecondGeneration Taxoids as Warheads. Accounts of Chemical Research, 41(1), 108-119. https://doi.org/10.1021/ar700093f

15 Russell-Jones, G., McTavish, K., McEwan, J., Rice, J., \& Nowotnik, D. (2004). Vitamin-mediated targeting as a potential mechanism to increase drug uptake by tumours. Journal of Inorganic Biochemistry, 98(10), 1625-1633. https://doi.org/10.1016/j.jinorgbio.2004.07.009

16 Chen, S., Zhao, X., Chen, J., Chen, J., Kuznetsova, L., Wong, S.S., \& Ojima, I. (2010). Mechanism-Based Tumor-Targeting Drug Delivery System. Validation of Efficient Vitamin Receptor-Mediated Endocytosis and Drug Release. Bioconjugate Chemistry, 21(5), 979-987. https://doi.org/10.1021/bc9005656

17 Leamon, C.P., \& Reddy, J.A. (2004). Folate-targeted chemotherapy. Advanced Drug Delivery Reviews, 56(8), $1127-1141$. https://doi.org/10.1016/j.addr.2004.01.008

18 Lu, Y., \& Low, P.S. (2002). Folate-mediated delivery of macromolecular anticancer therapeutic agents. Advanced Drug Delivery Reviews, 54(5), 675-693. https://doi.org/10.1016/S0169-409X(02)00042-X

19 Reddy, J.A., Westrick, E., Vlahov, I., Howard, S.J., Santhapuram, H.K., \& Leamon, C.P. (2006). Folate receptor specific antitumor activity of folate-mitomycin conjugates. Cancer Chemotherapy and Pharmacology, 58(2), 229-236. https://doi.org/10.1007/s00280-005-0151-z

20 Leamon, C.P., Reddy, J.A., Vlahov, I.R., Vetzel, M., Parker, N., Nicoson, J.S., Xu, L.-C., \& Westrick, E. (2005). Synthesis and Biological Evaluation of EC72: A New Folate-Targeted Chemotherapeutic. Bioconjugate Chemistry, 16(4), 803-811. https://doi.org/10.1021/bc049709b

21 Shi, H., Guo, J., Li, C., \& Wang, Z. (2015). A current review of folate receptor alpha as a potential tumor target in non-smallcell lung cancer. Drug Design, Development and Therapy, 9, 4989-4996. https://doi.org/10.2147/DDDT.S90670

22 Zhao, X., Li, H., \& Lee, R.J. (2008). Targeted drug delivery via folate receptors. Expert Opinion on Drug Delivery, 5(3), 309-319. https://doi.org/10.1517/17425247.5.3.309

23 Low, Philip Stewart, \& Kularatne, S.A. (2009). Folate-targeted therapeutic and imaging agents for cancer. Current Opinion in Chemical Biology, 13(3), 256-262. https://doi.org/10.1016/j.cbpa.2009.03.022

24 Lambert, N., Abdalla, A.E., Duan, X., \& Xie, J. (2017). Emerging drugs and drug targets against tuberculosis. Journal of Drug Targeting, 25(4), 296-306. https://doi.org/10.1080/1061186X.2016.1258705

25 Riccardi, G., Pasca, M.R., \& Buroni, S. (2009). Mycobacterium tuberculosis: Drug resistance and future perspectives. Future Microbiology, 4(5), 597-614. https://doi.org/10.2217/fmb.09.20

26 Tyagi. (n.d.). Role of Vitamins B, C, and D in the fight against tuberculosis. Retrieved January 18, 2021, from https://www.ijmyco.org/article.asp?issn=2212-5531; year=2017; volume=6; issue=4; spage=328; epage=332; aulast=Tyagi

27 Tomioka, H. (2006). Current Status of Some Antituberculosis Drugs and the Development of new Antituberculous Agents with Special Reference to their In Vitro and In Vivo Antimicrobial Activities. Current Pharmaceutical Design, 12(31), 4047-4070. https://doi.org/10.2174/138161206778743646

28 Ojima, I., Zuniga, E.S., Berger, W.T., \& Seitz, J.D. (2011). Tumor-targeting drug delivery of new-generation taxoids. Future Medicinal Chemistry, 4(1), 33-50. https://doi.org/10.4155/fmc.11.167 
29 Collins, D.A., \& Hogenkamp, H.P. (2009). Cobalamin conjugates useful as antitumor agents (United States Patent No. US20090060837A1). https://patents.google.com/patent/US20090060837A1/en

30 Weinshenker, N.M., West, F.G., Araneo, B.A., \& Li, W. (2007). Cobalamin conjugates for antitumor therapy (United States Patent No. US7232805B2). https://patents.google.com/patent/US7232805B2/en

31 Pettenuzzo, A., Pigot, R., \& Ronconi, L. (2017). Vitamin B12-Metal Conjugates for Targeted Chemotherapy and Diagnosis: Current Status and Future Prospects. European Journal of Inorganic Chemistry, 2017(12), 1625-1638. https://doi.org/10.1002/ejic.201601217

32 Krall, N., Scheuermann, J., \& Neri, D. (2013). Small Targeted Cytotoxics: Current State and Promises from DNA-Encoded Chemical Libraries. Angewandte Chemie International Edition, 52(5), 1384-1402. https://doi.org/10.1002/anie.201204631

33 Boulikas, T., Pantos, A., Bellis, E., \& Christofis, P. (n.d.). Designing platinum compounds in cancer: Structures and mechanisms, 48.

34 Akupec, M.A., Galanski, M., Arion, V.B., Hartinger, C.G., \& Keppler, B.K. (2007). Antitumour metal compounds: More than theme and variations. Dalton Transactions, 2, 183-194. https://doi.org/10.1039/B712656P

35 Kelland, L. (2007). The resurgence of platinum-based cancer chemotherapy. Nature Reviews Cancer, 7(8), $573-584$. https://doi.org/10.1038/nrc2167

36 Mundwiler, S., Spingler, B., Kurz, P., Kunze, S., \& Alberto, R. (2005). Cyanide-Bridged Vitamin B12-Cisplatin Conjugates. Chemistry - A European Journal, 11(14), 4089-4095. https://doi.org/10.1002/chem.200500117

37 Ruiz-Sánchez, P., König, C., Ferrari, S., \& Alberto, R. (2011). Vitamin B12 as a carrier for targeted platinum delivery: In vitro cytotoxicity and mechanistic studies. JBIC Journal of Biological Inorganic Chemistry, 16(1), 33-44. https://doi.org/10.1007/s00775-010-0697-z

38 Bagnato, J.D., Eilers, A.L., Horton, R.A., \& Grissom, C.B. (2004). Synthesis and Characterization of a Cobalamin-Colchicine Conjugate as a Novel Tumor-Targeted Cytotoxin. The Journal of Organic Chemistry, 69(26), 8987-8996. https://doi.org/10.1021/jo049953w

39 Kubler, P.A. (2000). Fatal colchicine toxicity. Medical Journal of Australia, 172(10), 498-499.

40 Iacobuzio-Donahue, C.A., Lee, E.L., Abraham, S.C., Yardley, J.H., \& Wu, T.-T. (2001). Colchicine Toxicity: Distinct Morphologic Findings in Gastrointestinal Biopsies. The American Journal of Surgical Pathology, 25(8), 1067-1073.

41 Kratz, F., Beyer, U., \& Schutte, M.T. (1999). Drug-Polymer Conjugates Containing Acid-Cleavable Bonds. Critical Reviews\&trade; in Therapeutic Drug Carrier Systems, 16(3). https://doi.org/10.1615/CritRevTherDrugCarrierSyst.v16.i3.10

42 Baker, M.A., Gray, B.D., Ohlsson-Wilhelm, B.M., Carpenter, D.C., \& Muirhead, K.A. (1996). Zyn-Linked colchicines: Controlled-release lipophilic prodrugs with enhanced antitumor efficacy. Journal of Controlled Release, 40(1), 89-100. https://doi.org/10.1016/0168-3659(95)00177-8

43 Mons, S., Veretout, F., Carlier, M.-F., Erk, I., Lepault, J., \& Trudel, E. et al. (2000). The interaction between lipid derivatives of colchicine and tubulin: Consequences of the interaction of the alkaloid with lipid membranes. Biochimica et Biophysica Acto (BBA) - Biomembranes, 1468(1), 381-395. https://doi.org/10.1016/S0005-2736(00)00279-0

44 Vlahov, I.R., \& Leamon, C.P. (2012). Engineering Folate-Drug Conjugates to Target Cancer: From Chemistry to Clinic. Bioconjugate Chemistry, 23(7), 1357-1369. https://doi.org/10.1021/bc2005522

45 Farran, B., Montenegro, R.C., Kasa, P., Pavitra, E., Huh, Y. S., \& Han, Y.-K. et al. (2020). Folate-conjugated nanovehicles: Strategies for cancer therapy. Materials Science and Engineering: C, 107, 110341. https://doi.org/10.1016/j.msec.2019.110341

46 Low, P.S., Henne, W.A., \& Doorneweerd, D.D. (2008). Discovery and Development of Folic-Acid-Based Receptor Targeting for Imaging and Therapy of Cancer and Inflammatory Diseases. Accounts of Chemical Research, 41(1), 120-129. https://doi.org/10.1021/ar7000815

47 Geersing, A., de Vries, R.H., Jansen, G., Rots, M.G., \& Roelfes, G. (2019). Folic acid conjugates of a bleomycin mimic for selective targeting of folate receptor positive cancer cells. Bioorganic \& Medicinal Chemistry Letters, 29(15), 1922-1927. https://doi.org/10.1016/j.bmcl.2019.05.047

48 Chiani, M., Norouzian, D., Shokrgozar, M.A., Azadmanesh, K., Najmafshar, A., Mehrabi, M.R., \& Akbarzadeh, A. (2018). Folic acid conjugated nanoliposomes as promising carriers for targeted delivery of bleomycin. Artificial Cells, Nanomedicine, and Biotechnology, 46(4), 757-763. https://doi.org/10.1080/21691401.2017.1337029

49 Blum, R.H., Carter, S.K., \& Agre, K. (1973). A clinical review of bleomycin - A new antineoplastic agent. Cancer, 31(4), 903-914. https://doi.org/10.1002/1097-0142(197304)31:4<903:: AID-CNCR2820310422>3.0.CO;2-N

50 Chung, K.N., Saikawa, Y., Paik, T.H., Dixon, K.H., Mulligan, T., Cowan, K.H., \& Elwood, P.C. (1993). Stable transfectants of human MCF-7 breast cancer cells with increased levels of the human folate receptor exhibit an increased sensitivity to antifolates. The Journal of Clinical Investigation, 91(4), 1289-1294. https://doi.org/10.1172/JCI116327

51 Lee, M.H., Sessler, J.L., \& Kim, J.S. (2015). Disulfide-Based Multifunctional Conjugates for Targeted Theranostic Drug Delivery. Accounts of Chemical Research, 48(11), 2935-2946. https://doi.org/10.1021/acs.accounts.5b00406

52 Pinhassi, R.I., Assaraf, Y.G., Farber, S., Stark, M., Ickowicz, D., \& Drori, S. et al. (2010). Arabinogalactan-Folic Acid-Drug Conjugate for Targeted Delivery and Target-Activated Release of Anticancer Drugs to Folate Receptor-Overexpressing Cells. Biomacromolecules, 11(1), 294-303. https://doi.org/10.1021/bm900853z

53 Ickowicz, D.E., Farber, S., Sionov, E., Kagan, S., Hoffman, A., Polacheck, I., \& Domb, A.J. (2014). Activity, Reduced Toxicity, and Scale-Up Synthesis of Amphotericin B-Conjugated Polysaccharide. Biomacromolecules, 15(6), 2079-2089. https://doi.org/10.1021/bm5002125

54 Duncan, R. (2003). The dawning era of polymer therapeutics. Nature Reviews Drug Discovery, 2(5), 347-360. https://doi.org/10.1038/nrd1088

55 Assaraf, Y.G. (2006). The role of multidrug resistance efflux transporters in antifolate resistance and folate homeostasis. Drug Resistance Updates, 9(4), 227-246. https://doi.org/10.1016/j.drup.2006.09.001 
56 Esmaeili, F., Ghahremani, M.H., Ostad, S.N., Atyabi, F., Seyedabadi, M., \& Malekshahi, M. R. et al. (2008). Folate-receptortargeted delivery of docetaxel nanoparticles prepared by PLGA-PEG-folate conjugate. Journal of Drug Targeting, 16(5), 415-423. https://doi.org/10.1080/10611860802088630

57 Kwon, G.S., \& Okano, T. (1996). Polymeric micelles as new drug carriers. Advanced Drug Delivery Reviews, 21(2), 107116. https://doi.org/10.1016/S0169-409X(96)00401-2

58 Guo, W., Lee, T., Sudimack, J., \& Lee, R.J. (2000). Receptor-Specific Delivery of Liposomes Via Folate-Peg-Chol. Journal of Liposome Research, 10(2-3), 179-195. https://doi.org/10.3109/08982100009029385

59 Yoo, H.S., \& Park, T.G. (2001). Biodegradable polymeric micelles composed of doxorubicin conjugated PLGA-PEG block co-polymer. Journal of Controlled Release, 70(1), 63-70. https://doi.org/10.1016/S0168-3659(00)00340-0

60 Yoo, H.S., \& Park, T.G. (2004). Folate-receptor-targeted delivery of doxorubicin nano-aggregates stabilized by doxorubicinPEG-folate conjugate. Journal of Controlled Release, 100(2), 247-256. https://doi.org/10.1016/j.jconrel.2004.08.017

61 Gabizon, A., Shmeeda, H., Horowitz, A. T., \& Zalipsky, S. (2004). Tumor cell targeting of liposome-entrapped drugs with phospholipid-anchored folic acid-PEG conjugates. Advanced Drug Delivery Reviews, 56(8), $1177-1192$. https://doi.org/10.1016/j.addr.2004.01.011

$62 \mathrm{H}$, M. (2001). The enhanced permeability and retention (EPR) effect in tumor vasculature: The key role of tumor-selective macromolecular drug targeting. Advances in Enzyme Regulation, 41, 189-207. https://doi.org/10.1016/s0065-2571(00)00013-3

63 Jain, R.K. (2001). Delivery of molecular medicine to solid tumors: Lessons from in vivo imaging of gene expression and function. Journal of Controlled Release, 74(1), 7-25. https://doi.org/10.1016/S0168-3659(01)00306-6

64 Gabizon, A., Horowitz, A.T., Goren, D., Tzemach, D., Mandelbaum-Shavit, F., Qazen, M.M., \& Zalipsky, S. (1999). Targeting Folate Receptor with Folate Linked to Extremities of Poly(ethylene glycol)-Grafted Liposomes: In Vitro Studies. Bioconjugate Chemistry, 10(2), 289-298. https://doi.org/10.1021/bc9801124

65 Gabizon, A., Horowitz, A.T., Goren, D., Tzemach, D., Shmeeda, H., \& Zalipsky, S. (2003). In Vivo Fate of Folate-Targeted Polyethylene-Glycol Liposomes in Tumor-Bearing Mice. Clinical Cancer Research, 9(17), 6551-6559.

66 Wang, Y., Li, P., Chen, L., Gao, W., Zeng, F., \& Kong, L.X. (2015). Targeted delivery of 5-fluorouracil to HT-29 cells using high efficient folic acid-conjugated nanoparticles. Drug Delivery, 22(2), 191-198. https://doi.org/10.3109/10717544.2013.875603

67 Chen, Y.-S., Alany, R.G., Young, S.A., Green, C.R., \& Rupenthal, I.D. (2011). In vitro release characteristics and cellular uptake of poly(D,L-lactic-co-glycolic acid) nanoparticles for topical delivery of antisense oligodeoxynucleotides. Drug Delivery, 18(7), 493-501. https://doi.org/10.3109/10717544.2011.589088

68 Anfi, L., Guanti, G., \& Riva, R. (1999). Synthesis of asymmetrized 2-benzyl-1,3-diaminopropane by a chemoenzymatic route: A tool for combinatorially developing peptidomimetics. Tetrahedron: Asymmetry, 10(18), 3571-3592. https://doi.org/10.1016/S0957-4166(99)00371-7

69 Gupta, Y., Jain, A., Jain, P., \& Jain, S.K. (2007). Design and development of folate appended liposomes for enhanced delivery of 5-FU to tumor cells. Journal of Drug Targeting, 15(3), 231-240. https://doi.org/10.1080/10611860701289719

70 Sharma, M., Malik, R., Verma, A., Dwivedi, P., Banoth, G.S., \& Pandey, N. et al. (2013). Folic Acid Conjugated Guar Gum Nanoparticles for Targeting Methotrexate to Colon Cancer. Journal of Biomedical Nanotechnology, 9(1), 96-106. https://doi.org/10.1166/jbn.2013.1474

71 Praetorius, N.P., \& Mandal, T.K. (2007). Engineered Nanoparticles in Cancer Therapy. Recent Patents on Drug Delivery \& Formulation, 1(1), 37-51. https://doi.org/10.2174/187221107779814104

72 Soppimath, K.S., Aminabhavi, T.M., Kulkarni, A.R., \& Rudzinski, W.E. (2001). Biodegradable polymeric nanoparticles as drug delivery devices. Journal of Controlled Release, 70(1), 1-20. https://doi.org/10.1016/S0168-3659(00)00339-4

73 Chourasia, M.K., \& Jain, S.K. (2004a). Polysaccharides for Colon Targeted Drug Delivery. Drug Delivery, 11(2), $129-148$. https://doi.org/10.1080/10717540490280778

74 Chourasia, M.K., \& Jain, S.K. (2004b). Potential of Guar Gum Microspheres for Target Specific Drug Release to Colon. Journal of Drug Targeting, 12(7), 435-442. https://doi.org/10.1080/10611860400006604

75 Thomas, T.P., Huang, B., Choi, S.K., Silpe, J.E., Kotlyar, A., \& Desai, A.M. et al. (2012). Polyvalent DendrimerMethotrexate as a Folate Receptor-Targeted Cancer Therapeutic. Molecular Pharmaceutics, 9(9), $2669-2676$. https://doi.org/10.1021/mp3002232

76 Nanjwade, B.K., Bechra, H.M., Derkar, G K., Manvi, F.V., \& Nanjwade, V.K. (2009). Dendrimers: Emerging polymers for drug-delivery systems. European Journal of Pharmaceutical Sciences, 38(3), 185-196. https://doi.org/10.1016/j.ejps.2009.07.008

77 Quintana, A., Raczka, E., Piehler, L., Lee, I., Myc, A., \& Majoros, I. et al. (2002). Design and Function of a DendrimerBased Therapeutic Nanodevice Targeted to Tumor Cells Through the Folate Receptor. Pharmaceutical Research, 19(9), $1310-1316$. https://doi.org/10.1023/A:1020398624602

78 Majoros, I.J., Thomas, T.P., Mehta, C.B., \& Baker, J.R. (2005). Poly(amidoamine) Dendrimer-Based Multifunctional Engineered Nanodevice for Cancer Therapy. Journal of Medicinal Chemistry, 48(19), 5892-5899. https://doi.org/10.1021/jm0401863

79 Majoros, I.J., Williams, C.R., Becker, A., \& Baker, J.R. (2009). Methotrexate delivery via folate targeted dendrimer-based nanotherapeutic platform. WIREs Nanomedicine and Nanobiotechnology, 1(5), 502-510. https://doi.org/10.1002/wnan.37

80 Mullen, D.G., Fang, M., Desai, A., Baker, J.R., Orr, B.G., \& Banaszak Holl, M.M. (2010). A Quantitative Assessment of Nanoparticle-Ligand Distributions: Implications for Targeted Drug and Imaging Delivery in Dendrimer Conjugates. ACS Nano, 4(2), 657-670. https://doi.org/10.1021/nn900999c

81 Gillies, E.R., \& Fréchet, J.M.J. (2005). Dendrimers and dendritic polymers in drug delivery. Drug Discovery Today, 10(1), 35-43. https://doi.org/10.1016/S1359-6446(04)03276-3

82 Zhang, Y., Thomas, T.P., Desai, A., Zong, H., Leroueil, P.R., Majoros, I.J., \& Baker, J.R. (2010). Targeted Dendrimeric Anticancer Prodrug: A Methotrexate-Folic Acid-Poly(amidoamine) Conjugate and a Novel, Rapid, «One Pot» Synthetic Approach. Bioconjugate Chemistry, 21(3), 489-495. https://doi.org/10.1021/bc9003958

83 Tripodo, G., Mandracchia, D., Collina, S., Rui, M., \& Rossi, D. (2014). New Perspectives in Cancer Therapy: The BiotinAntitumor Molecule Conjugates. Open Access, 8. 
84 Maiti, Santanu, \& Paira, P. (2018). Biotin conjugated organic molecules and proteins for cancer therapy: A review. European Journal of Medicinal Chemistry, 145, 206-223. https://doi.org/10.1016/j.ejmech.2018.01.001

85 Yang, W., Cheng, Y., Xu, T., Wang, X., \& Wen, L. (2009). Targeting cancer cells with biotin-dendrimer conjugates. European Journal of Medicinal Chemistry, 44(2), 862-868. https://doi.org/10.1016/j.ejmech.2008.04.021

86 Maiti, Sukhendu, Park, N., Han, J.H., Jeon, H.M., Lee, J.H., Bhuniya, S., Kang, C., \& Kim, J.S. (2013). GemcitabineCoumarin-Biotin Conjugates: A Target Specific Theranostic Anticancer Prodrug. Journal of the American Chemical Society, 135(11), 4567-4572. https://doi.org/10.1021/ja401350x

87 Lee, M.H., Kim, J.Y., Han, J.H., Bhuniya, S., Sessler, J.L., Kang, C., \& Kim, J.S. (2012). Direct fluorescence monitoring of the delivery and cellular uptake of a cancer-targeted RGD peptide-appended naphthalimide theragnostic prodrug. Journal of the American Chemical Society, 134(30), 12668-12674.

88 Cordero, F.M., Bonanno, P., Chioccioli, M., Gratteri, P., Robina, I., Moreno Vargas, A. J., \& Brandi, A. (2011). Diversityoriented syntheses of 7-substituted lentiginosines. Tetrahedron, 67(49), 9555-9564. https://doi.org/10.1016/j.tet.2011.10.008

89 Gregory, J.D. (2002, May 1). The Stability of N-Ethylmaleimide and its Reaction with Sulfhydryl Groups (world). American Chemical Society. https://doi.org/10.1021/ja01619a073

90 Neuzil, J., Weber, T., Gellert, N., \& Weber, C. (2001). Selective cancer cell killing by $\alpha$-tocopheryl succinate. British Journal of Cancer, 84(1), 87-89. https://doi.org/10.1054/bjoc.2000.1559

91 Rathod, S., Bahadur, P., \& Tiwari, S. (2021). Nanocarriers based on vitamin E-TPGS: Design principle and molecular insights into improving the efficacy of anticancer drugs. International Journal of Pharmaceutics, 592, 120045. https://doi.org/10.1016/j.ijpharm.2020.120045

92 Abu-Fayyad, A., \& Nazzal, S. (2017). Gemcitabine-vitamin E conjugates: Synthesis, characterization, entrapment into nanoemulsions, and in-vitro deamination and antitumor activity. International Journal of Pharmaceutics, 528(1), 463-470. https://doi.org/10.1016/j.ijpharm.2017.06.031

93 Andersson, R., Aho, U., Nilsson, B.I., Peters, G.J., Pastor-Anglada, M., Rasch, W., \& Sandvold, M.L. (2009). Gemcitabine chemoresistance in pancreatic cancer: Molecular mechanisms and potential solutions. Scandinavian Journal of Gastroenterology, 44(7), 782-786. https://doi.org/10.1080/00365520902745039

94 Abu-Fayyad, A., Behery, F., Sallam, A.A., Alqahtani, S., Ebrahim, H., \& El Sayed, K.A. et al. (2015). PEGylated $\gamma$-tocotrienol isomer of vitamin E: Synthesis, characterization, in vitro cytotoxicity, and oral bioavailability. European Journal of Pharmaceutics and Biopharmaceutics, 96, 185-195. https://doi.org/10.1016/j.ejpb.2015.07.022

95 Lansakara-P., D.S.P., Rodriguez, B.L., \& Cui, Z. (2012). Synthesis and in vitro evaluation of novel lipophilic monophosphorylated gemcitabine derivatives and their nanoparticles. International Journal of Pharmaceutics, 429(1), $123-134$. https://doi.org/10.1016/j.ijpharm.2012.03.014

96 Cateni, F., Zacchigna, M., \& Procida, G. (2020). Synthesis and controlled drug delivery studies of a novel UbiquinolPolyethylene glycol-Vitamin E adduct. Bioorganic Chemistry, 105, 104329. https://doi.org/10.1016/j.bioorg.2020.104329

97 Bhagavan, H.N., \& Chopra, R.K. (2006). Coenzyme Q10: Absorption, tissue uptake, metabolism and pharmacokinetics. Free Radical Research, 40(5), 445-453. https://doi.org/10.1080/10715760600617843

98 James, A.M., Smith, R.A.J., \& Murphy, M.P. (2004). Antioxidant and prooxidant properties of mitochondrial Coenzyme Q. Archives of Biochemistry and Biophysics, 423(1), 47-56. https://doi.org/10.1016/j.abb.2003.12.025

99 Cervellati, R., \& Greco, E. (2016). In vitro Antioxidant Activity of Ubiquinone and Ubiquinol, Compared to Vitamin E. Helvetica Chimica Acta, 99(1), 41-45. https://doi.org/10.1002/hlca.201500124

100 Iwata, R., Nakayama, F., Hirochi, S., Sato, K., Piao, W., \& Nishina, K. et al. (2015). Synthesis and properties of vitamin E analog-conjugated neomycin for delivery of RNAi drugs to liver cells. Bioorganic \& Medicinal Chemistry Letters, 25(4), 815-819. https://doi.org/10.1016/j.bmcl.2014.12.079

101 Desigaux, L., Sainlos, M., Lambert, O., Chevre, R., Letrou-Bonneval, E., \& Vigneron, J.-P. et al. (2007). Self-assembled lamellar complexes of siRNA with lipidic aminoglycoside derivatives promote efficient siRNA delivery and interference. Proceedings of the National Academy of Sciences, 104(42), 16534-16539. https://doi.org/10.1073/pnas.0707431104

102 Kutty, R.V., \& Feng, S.-S. (2013). Cetuximab conjugated vitamin E TPGS micelles for targeted delivery of docetaxel for treatment of triple negative breast cancers. Biomaterials, 34(38), 10160-10171. https://doi.org/10.1016/j.biomaterials.2013.09.043

103 Nguyen, P., Taghian, A., Katz, M., Niemierko, A., Raad, R., \& Boon, W. et al. (2008). Breast Cancer Subtype Approximated by Estrogen Receptor, Progesterone Receptor, and HER-2 Is Associated With Local and Distant Recurrence After BreastConserving Therapy. Journal of Clinical Oncology: Official Journal of the American Society of Clinical Oncology, 26, $2373-2378$. https://doi.org/10.1200/JCO.2007.14.4287

104 Muthu, M.S., Avinash Kulkarni, S., Liu, Y., \& Feng, S.-S. (2012). Development of docetaxel-loaded vitamin E TPGS micelles: Formulation optimization, effects on brain cancer cells and biodistribution in rats. Nanomedicine, 7(3), 353-364. https://doi.org/10.2217/nnm.11.111

105 Wong, C., \& Chen, S. (2012). The development, application and limitations of breast cancer cell lines to study tamoxifen and aromatase inhibitor resistance. The Journal of Steroid Biochemistry and Molecular Biology, 131(3), 83-92. https://doi.org/10.1016/j.jsbmb.2011.12.005

106 Luo, S., Wang, Z., Patel, M., Khurana, V., Zhu, X., Pal, D., \& Mitra, Ashim. K. (2011). Targeting SVCT for enhanced drug absorption: Synthesis and in vitro evaluation of a novel vitamin $\mathrm{C}$ conjugated prodrug of saquinavir. International Journal of Pharmaceutics, 414(1), 77-85. https://doi.org/10.1016/j.ijpharm.2011.05.001

107 Boyer, J.C., Campbell, C.E., Sigurdson, W.J., \& Kuo, S.-M. (2005). Polarized localization of vitamin C transporters, SVCT1 and SVCT2, in epithelial cells. Biochemical and Biophysical Research Communications, 334(1), 150-156. https://doi.org/10.1016/j.bbrc.2005.06.069

108 Varma, M.V.S., Ashokraj, Y., Dey, C.S., \& Panchagnula, R. (2003). P-glycoprotein inhibitors and their screening: A perspective from bioavailability enhancement. Pharmacological Research, 48(4), 347-359. https://doi.org/10.1016/S10436618(03)00158-0 
109 Luo, S., Wang, Z., Kansara, V., Pal, D., \& Mitra, Ashim, K. (2008). Activity of a sodium-dependent vitamin C transporter (SVCT) in MDCK-MDR1 cells and mechanism of ascorbate uptake. International Journal of Pharmaceutics, 358(1), $168-176$. https://doi.org/10.1016/j.ijpharm.2008.03.002

110 Pandit, S., Roy, S., Pillai, J., \& Banerjee, S. (2020). Formulation and Intracellular Trafficking of Lipid-Drug Conjugate Nanoparticles Containing a Hydrophilic Anti-tubercular Drug for Improved Intracellular Delivery to Human Macrophages. ACS Omega, 5(9), 4433-4448. https://doi.org/10.1021/acsomega.9b03523

111 Thalla, M., Gangasani, J., Saha, P., Ponneganti, S., Borkar, R.M., \& Naidu, V. et al. (2020). Synthesis, Characterizations, and Use of O-Stearoyl Mannose Ligand-Engineered Lipid Nanoarchitectonics for Alveolar Macrophage Targeting. ASSAY and Drug Development Technologies. https://doi.org/10.1089/adt.2020.999

112 Alven, S., Nqoro, X., Buyana, B., \& Aderibigbe, B.A. (2020). Polymer-Drug Conjugate, a Potential Therapeutic to Combat Breast and Lung Cancer. Pharmaceutics, 12(5), 406. https://doi.org/10.3390/pharmaceutics12050406

113 Elvira, C., Gallardo, A., Roman, J., \& Cifuentes, A. (2005). Covalent Polymer-Drug Conjugates. Molecules, 10(1), 114125. https://doi.org/10.3390/10010114

114 Kakde, D., Jain, D., Shrivastava, V., Kakde, R., \& Patil, A.T. (n.d.). Cancer Therapeutics- Opportunities, Challenges and Advances in Drug Delivery. Journal of Applied Pharmaceutical Science, 10.

115 Suksiriworapong, J., Taresco, V., Ivanov, D.P., Styliari, I.D., Sakchaisri, K., Junyaprasert, V.B., \& Garnett, M.C. (2018). Synthesis and properties of a biodegradable polymer-drug conjugate: Methotrexate-poly(glycerol adipate). Colloids and Surfaces B: Biointerfaces, 167, 115-125. https://doi.org/10.1016/j.colsurfb.2018.03.048

116 Karimi, N., Soleiman-Beigi, M., \& Fattahi, A. (2020). Co-delivery of all-trans-retinoic acid and docetaxel in drug conjugated polymeric nanoparticles: Improving controlled release and anticancer effect. Materials Today Communications, $25,101280$. https://doi.org/10.1016/j.mtcomm.2020.101280

117 Liu, X.-M., Quan, L.-D., Tian, J., Alnouti, Y., Fu, K., Thiele, G.M., \& Wang, D. (2008). Synthesis and Evaluation of a Well-defined HPMA Copolymer-Dexamethasone Conjugate for Effective Treatment of Rheumatoid Arthritis. Pharmaceutical Research, 25(12), 2910-2919. https://doi.org/10.1007/s11095-008-9683-3

\title{
Р.П. Бхоле, Йогита Шинде, Ч.Г. Бонде, Р.Д. Вавхейл \\ Дәруменді дәрілік конъюгат: фармакологиялық потенциалын жүйелі түрде талдау
}

\begin{abstract}
Қатерлі ісік өлімге әкелуі мүмкін созылмалы ауру болып табылады. Дәстүрлі химиотерапияда цитотоксикалық препараттар көбейіп бара жатқан қатерлі ісік жасушаларын жою үшін қолданылады. Цитоуытты агенттің талғамдығы төмен болады, биологиялық белсенділік танытпайды, жүйелік уыттылық пен жағымсыз әсер етеді. Жыл сайын халықтың 1,8 миллионға жуығы туберкулез инфекциясын жұқтырып, соның салдарынан қайтыс болады. Туберкулезді емдеу кезінде дәрілік затқа төзімділіктің жоғарылауы маңызды мәселе болып табылады. Сонымен, дәріге тұрақтылықты, туберкулез инфекциясындағы дәрілік селективтілікті және цитоуытты агент пен туберкулезге қарсы препараттардың жанама әсерлерін азайтуды шешудің жаңа әдісін немесе терапиясын жасау өте өзекті мәселе. Бұл шолу мақалада жаңадан пайда болған «дәрумен-дәрілік конъюгаты» тұжырымдамасы сипатталған. Дәрумен-дәрілік конъюгат - бұл мақсатты орынға қарай арнайы жеткізілетін препарат, қатерлі ісік және туберкулез сияқты созылмалы ауруларды емдеудің және терапевтік нәтижелерді жақсартудың перспективалы әдістерінің бірі. Жұмыстың мақсаты - жаңа қатерлі ісікке және туберкулезге қарсы препараттың құрамына кіретін дәруменнің әсерін зерттеуге, селективті емес, жүйелік уыттылық және көп дәрілікке төзімділік сияқты қиындықтарды жеңуге бағытталған. Бұл тәсіл өмірге қауіп төндіретін қатерлі ісік, туберкулез сияқты ауруларды емдеуде және көптеген вирустық инфекцияларда тиімді.
\end{abstract}

Кілт сөздер: қатерлі ісік, туберкулез, дәрумен-дәрілік конъюгаты, В12 дәрумені конъюгаты, фолий қышқылының конъюгаты, биотин конъюгаты, Е дәрумені конъюгаты, липидті дәрі конъюгаты.

\section{Р.П. Бхоле, Йогита Шинде, Ч.Г. Бонде, Р.Д. Вавхейл Конъюгат витамин - лекарственный препарат:
систематический обзор фармакологического потенциала}

Рак является хроническим заболеванием, которое может привести к смерти. В традиционной химиотерапии цитотоксические препараты используются для уничтожения пролиферирующих раковых клеток. Цитотоксический агент обладает меньшей специфичностью и биологической активностью, также вызывает системную токсичность и нежелательные побочные эффекты. Ежегодно около 1,8 миллиона человек заражаются и умирают от туберкулезной инфекции. Повышение лекарственной устойчивости во время лечения туберкулеза вызывает серьезную озабоченность. Таким образом, необходимо разработать новый подход или методы лечения для устранения лекарственной устойчивости, лекарствен- 
ной селективности при туберкулезной инфекции и уменьшения побочных эффектов цитотоксических агентов и противотуберкулезных препаратов. В данной обзорной статье описано недавно появившееся понятие «витаминно-лекарственный конъюгат». Конъюгат витамин-лекарство - препарат, который специально доставляется к месту назначения, и один из многообещающих способов лечения хронических заболеваний, таких как рак и туберкулез, и улучшения терапевтического результата. Цель работы - изучить витамин как целевую составляющую для нового противоопухолевого и противотуберкулезного препарата при преодолении таких проблем, как неселективность, системная токсичность и множественная лекарственная устойчивость. Этот подход полезен и при лечении опасных для жизни заболеваний, таких как вирусные инфекции.

Ключевые слова: рак, туберкулез, конъюгат витамин - лекарство, конъюгат витамина В12, конъюгат фолиевой кислоты, конъюгат биотина, конъюгат витамина Е, конъюгат липид - лекарственный препарат.

\section{Information about authors}

Bhole, Ritesh Prakash - PhD, Associate Professor, Dr. D. Y. Patil Institute of Pharmaceutical Sciences and Research, Sant Tukaram Nagar, Pimpri, Pune-411018, India: email ritesh.bhole@dypvp.edu.in; https://orcid.org/0000-0003-4088-7470

Bonde, Chandrakant Ghansham - PhD, Professor, SPTM, NMIMS, School of Pharmacy, Shirpur, Dist: Dhule, India. Email: chandrakant.bonde@nmims.edu; https://orcid.org/0000-0001-5712-1119

Shinde, Yogita - M. Pharm, Research Scholar, Dr. D.Y. Patil Institute of Pharmaceutical Sciences and Research, Sant Tukaram Nagar, Pimpri, Pune-411018, India; email: shindeyogita48@gmail.com.

Wavhale, Ravindra - PhD, Assistant Professor, Dr. D.Y. Patil Institute of Pharmaceutical Sciences and Research, Sant Tukaram Nagar, Pimpri, Pune-411018; ravindra.wavhale@dypvp.edu.in, https://orcid.org/0000-0003-1614-9742 